
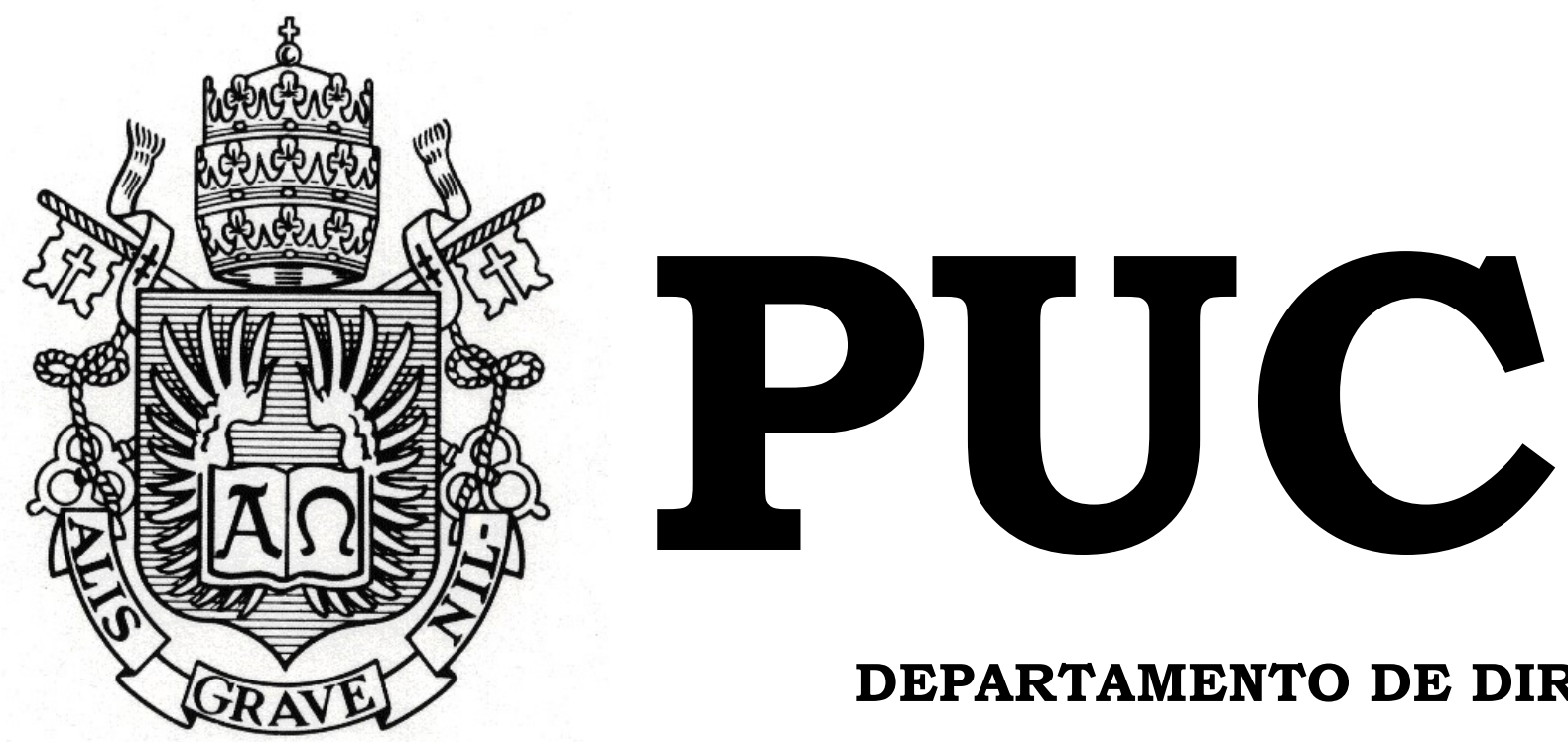

DEPARTAMENTO DE DIREITO

\title{
ONLINE DISPUTE RESOLUTIONS - UM ESTUDO DA ARBITRAGEM ONLINE OFERECIDA PELA COMPANHIA JUR
}

\author{
por \\ CONSTANÇA BURITY SIMÕES BARBOSA
}

ORIENTADOR: Pedro Paulo Cristofaro

2019.2

PONTIFÍCIA UNIVERSIDADE CATÓLICA DO RIO DE JANEIRO

RUA MARQUÊS DE SÃO VICENTE, 225 - CEP 22453-900

RIO DE JANEIRO - BRASIL 


\title{
ONLINE DISPUTE RESOLUTIONS - UM ESTUDO DA ARBITRAGEM ONLINE OFERECIDA PELA COMPANHIA JUR
}

\author{
por \\ CONSTANÇA BURITY SIMÕES BARBOSA
}

Monografia apresentada ao

Departamento de Direito da

Pontificia Universidade Católica do

Rio de Janeiro (PUC-Rio) para a obtenção do Título de Bacharel em Direito.

Orientador(a): Pedro Paulo Cristofaro 


\section{Agradecimentos}

Agradeço em primeiro lugar à minha família: à minha mãe, que entre mimos e cobranças me deu o apoio necessário durante todo esse trabalho; ao meu irmão, que com sua tranquilidade invejável me trouxe calma nos momentos de maior nervosismo; à minha chará, minha vó, por ser minha incentivadora $\mathrm{n}^{\mathrm{o}} 1$; e claro, uma agradecimento especial ao meu pai, meu exemplo não só profissional, como de vida, a quem eu tenho muita admiração e carinho.

Ao Dr. Pedro Paulo Cristofaro por toda a atenção e interesse e por todos os ensinamentos não apenas durante a elaboração deste trabalho como durante toda a minha trajetória no mundo jurídico.

Ao Julian Chediak cujo constante interesse pela inovação foi de grande inspiração para este trabalho.

Agradeço aos meus colegas de curso e de escritório, que estiveram ao meu lado durante tudo nessa graduação, em especial a Sofia Grunewald, Ana Paula Rodrigues, Lucca Bruzzi, Joana Mendes, Chantal Machado, André Cristofaro, Rafaela Marsillac, Gabriela Lopes, Maria Eduarda Falkenbach.

Por fim, agradeço às minhas amigas e amigos por todos os conselhos e momentos de descontração ao longo desse processo. 


\section{Resumo}

BARBOSA, Constança Burity Simões. Online Dispute Resolutions - um estudo sobre a arbitragem online oferecida pela companhia JUR. Rio de Janeiro. 2019. p. 71. Monografia (Graduação em Direito) Departamento de Direito da Pontifícia Universidade Católica do Rio de Janeiro - PUCRio.

O presente trabalho busca analisar a compatibilidade da arbitragem online conforme oferecida pela companhia suíça JUR com o ordenamento jurídico brasileiro, sobretudo com relação à lei de arbitragem.

Palavras Chave: Online Dispute Resolution - Alternative Dispute Resolution - Arbitragem - Blockchain - Arbitragem Online - Autonomia da Vontade - Convenção de Arbitragem - Indicação de Árbitro - Procedimento Arbitral - Sentença. 


\section{Sumário}

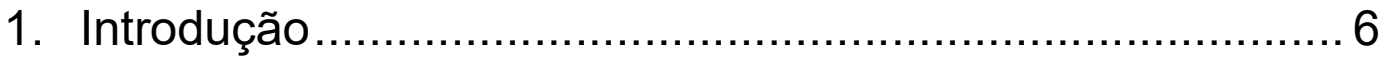

2. Online Dispute Resolution............................................. 8

2.1. Um Breve Histórico dos Online Dispute Resolutions............................11

2.1.1. O Surgimento dos ODRs............................................................ 11

2.1.2. Porque surgiram os ODRs? …………………........................... 13

2.2. A Redução de Custos Proporcionada pelos ODRs .............................16

3. Blockchain ................................................................. 18

4. A Companhia JUR ................................................... 22

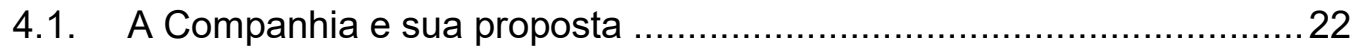

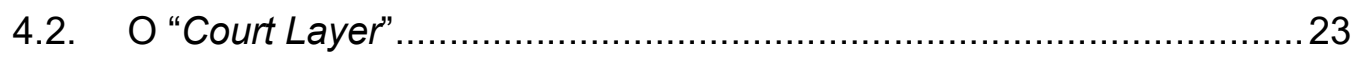

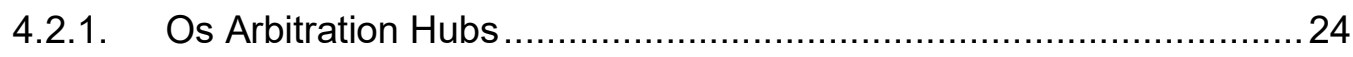

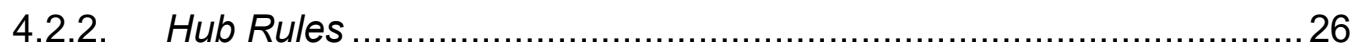

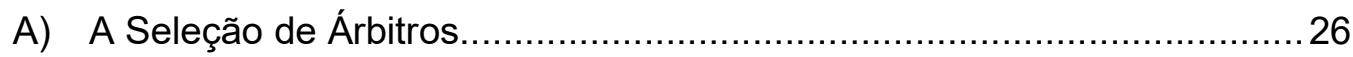

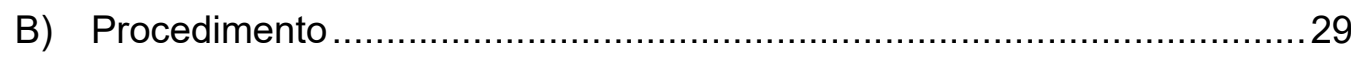

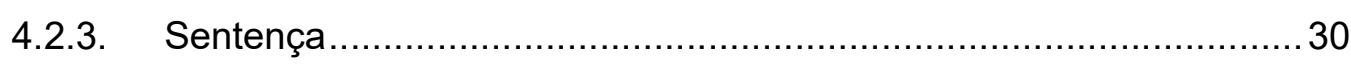

5. A plataforma do Court Layer da JUR à luz da Lei de Arbitragem Brasileira ........................................................... 33

5.1. Arbitragem e a Autonomia da Vontade das Partes ............................ 33

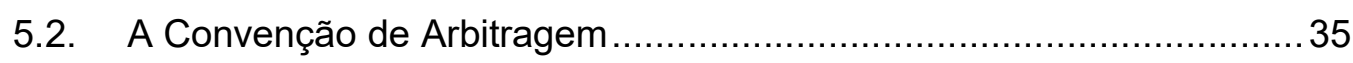

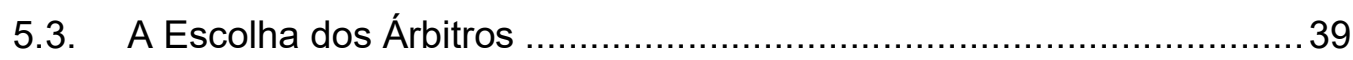

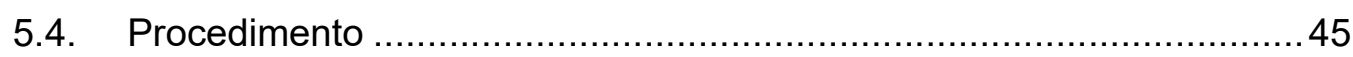

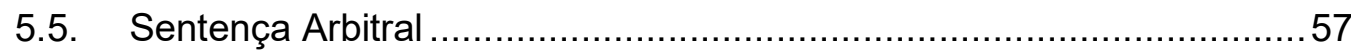

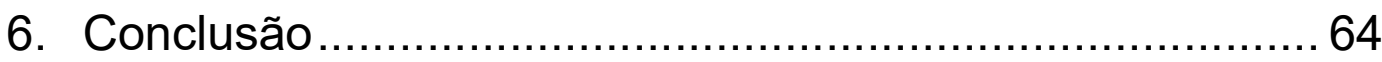




\section{Abreviações e Termos Definidos}

ABA Task Force - American Bar Association Task Force on E-Commerce and $A D R$

ADR - Alternative Dispute Resolution

CCI - Câmara de Comércio Internacional

Lei de Arbitragem - Lei 9.307 de 23 de setembro de 1996

ORD - Online Dispute Resolution 


\section{Introdução}

Nos últimos anos a arbitragem tem assumido um papel de protagonismo na resolução de disputas no Brasil. A tendência de optar pela via arbitral surge como uma reação a um judiciário ineficiente, marcado por uma grande morosidade e por decisões pouco técnicas e imprevisíveis.

Nesse contexto, a arbitragem se apresenta como uma forma de se solucionar disputas com mais celeridade e com a possibilidade de se escolher árbitros que sejam especialistas no objeto da controvérsia e que possam com isso proferir decisões de melhor qualidade.

Não obstante os benefícios que a arbitragem pode apresentar com relação ao judiciário, a arbitragem tradicional como é hoje conduzida ainda encontra uma série de limites relativos ao tipo de parte que pode ter acesso e ao tipo de conflito que pode ser resolvido por este meio.

A arbitragem, de forma geral, apresenta custos relativamente altos e muitas vezes não consegue atender às partes com a celeridade que se espera. Assim, disputas de pequeno ou médio porte não têm seus interesses suficientemente atendidos pela arbitragem. Por outro lado, essas disputas de menor valor também não encontram uma tutela satisfatória no judiciário, ficando em um certo limbo em que seus interesses não são atendidos.

Os Online Dispute Resolutions enxergaram nas tecnologias hoje disponíveis uma forma de simplificar métodos tradicionais de resolução de disputas, reduzindo significativamente os custos e a duração dos procedimentos de resolução de disputas.

São inúmeros os diferentes tipos de produtos desenvolvidos pelas plataformas que oferecem Online Dispute Resolutions. O presente trabalho 
terá como objeto a análise da arbitragem conduzida online, com enfoque no procedimento arbitral online oferecido pela companhia suíça, JUR, buscando analisar a compatibilidade deste procedimento com a legislação brasileira referente à arbitragem.

Para tanto, a presente monografia analisará primeiro alguns conceitos básicos necessários para a compreensão do trabalho. Assim o trabalho abordará um histórico e uma conceitualização das Online Dispute Resolutions, bem como da sistemática da tecnologia do blockchain que é a tecnologia utilizada pela JUR para viabilizar sua plataforma de Online Dispute Resolutions.

Em seguida será apresentada a plataforma oferecida pela JUR, explicando em maior detalhe como funciona o procedimento online de arbitragem por ela oferecido.

Por fim, será analisada a compatibilidade do procedimento arbitral online oferecido pela companhia suíça JUR com o ordenamento jurídico brasileiro, sobretudo com relação à Lei de Arbitragem Brasileira. 


\section{Online Dispute Resolution}

Antes de começar a tratar das Online Dispute Resolutions (" $\underline{O D R}$ ") é preciso definir o que se entende por Online Dispute Resolution. Conforme explicam Gabrielle Kaufmann-Kohler e Thomas Schultz há duas definições tradicionais de $O D R^{1}$ : (i) como uma forma sui generis de resolução de disputas ou (ii) como um método de resolução de disputas alternativo realizado de forma online ${ }^{2}$.

Ambas as definições acima mencionadas apresentam limitações e se mostram de certa forma insuficientes para definir o instituto. Isso porque definir as ODRs como sendo uma forma sui generis de resolver disputas acaba por ignorar todo o contexto em que se inserem, como se esta forma de resolução de disputas se encontrasse em um limbo jurídico sobre o qual as regras de resolução de disputas tradicionais, realizadas offline, não seriam aplicáveis ${ }^{3}$.

Uma arbitragem, que se utilize de uma plataforma de $O D R$ e seja conduzida de forma online, para ter a validade e a eficácia de uma arbitragem conforme definida em Lei, deve seguir rigorosamente todos os requisitos e limites determinados pela legislação aplicável, da mesma forma que uma arbitragem conduzida offline. O mesmo se dá com relação aos demais métodos de resolução de conflitos, como por exemplo a mediação. Vejam-se

\footnotetext{
1 "ODR is usually defined either as a sui generis form of dispute resolution or as online alternative dispute resolution (online ADR). These definitions shed light on important aspects of ODR - the sui generis approach focuses on the fact that new tools allow new dispute resolution procedures, while the online ADR perspective allows taking the developments of ADR into consideration". (KAUFMANN-KOHLER, Gabrielle. SCHULTZ, Thomas. Online Dispute Resolution: Challenges for Contemporary Justice. Hague: Kluwer Law International, 2004. p. 5)

${ }^{2} \mathrm{O}$ presente trabalho adota a definição clássica de métodos alternativos de disputa, os quais são definidos como sendo formas de resolver conflitos e litígios entre partes sem que se recorra ao judiciário ou a um tribunal arbitral. Os tipos mais comuns e mais difundidos de ADR, como são chamados, são a mediação, negociação e conciliação.

${ }^{3}$ KAUFMANN-KOHLER, Gabrielle. SCHULTZ, Op.Cit. p. 6
} 
abaixo as considerações de Gabrielle Kaufmann-Kohler e Thomas Schultz sobre o tema:

The negative aspect of the definition of ODR as a sui generis form of dispute resolution is that it tends to view ODR in a legal vacuum, as if the rules developed for offline dispute settlement did not exist and did not carry an important knowledge base. If an ODR process is meant to produce and outcome that is legally binding and enforceable in a manner comparable to a court judgment, it must qualify as arbitration and meet the requirement of the rules applicable to arbitration. If an ODR process is meant to bring the parties to a settlement through the intervention of a neutral third party, it would be wise to draw on the experience of offline mediation. ODR has its origins in different fields, and defining it as a sui generis method of dispute resolution ignores these origins ${ }^{4}$.

Ressaltam ainda os autores que definir as $O D R s$ como um método de resolução de disputas alternativo realizado de forma online também encontra obstáculos na medida em que restringe as $O D R s$ apenas aos métodos alternativos de resolução de disputa, excluindo portanto os métodos mais tradicionais de resolução de disputa que venham a ser realizados utilizando ferramentas online:

The problem with defining ODR as online alterative dispute resolutions is that it does not cover non-alternative dispute resolution methods, namely cybercourts, which are developed for some of the same reasons as online mediation or arbitration - for ease of access, lower costs and speed. Consequently, presenting $O D R$ as a mere extension of ADR would not reflect all of its possible applications and goals ${ }^{5}$.

Outro problema que se apresenta ao se tentar definir as ODRs é a extensão dos procedimentos que devem ser conduzidos online para que tal procedimento seja classificado como sendo um $O D R$. Por óbvio, não se discute que tais procedimentos, como o próprio nome indica, devam ser conduzidos online, mas qual o limite disso?

Hoje, por exemplo, é muito comum que as partes em uma arbitragem estabeleçam que não serão submetidas vias físicas de anexos, sendo todo o processo instruído com vias eletrônicas dos anexos. Isso é suficiente para se

\footnotetext{
${ }^{4}$ Ibid. p. 6

5 Ibid. p. 6.
} 
caracterizar um $O D R$ ? E se as manifestações das partes e do tribunal também se derem de forma exclusivamente digital, está se tratando de um $O D R$ ? E a realização de eventuais audiências, perícias, etc... como ficam na definição de ODRS?

Vejamos a definição trazida pela American Bar Association Task Force on E-Commerce and ADR, também referida como a ABA Task Force:

$O D R$ is a broad term that encompasses many forms of ADR and court proceedings that incorporate the use of Internet, websites, email communications, streaming media and other information technology as part of the dispute resolution process. Parties may never meet face to face when participating in an ODR. Rather, they might communicate solely online ${ }^{6}$.

A definição adotada pela $A B A$ Task Force é, portanto mais ampla, não apresentando parâmetros exatos para o que entende como sendo $O D R$, bastando que o uso de ferramentas online permeie o procedimento de resolução de disputa.

A Consumers International ${ }^{7}$ por outro lado, traz uma definição mais restrita do que seria $O D R$ :

Online dispute resolution [is] the term we use in this report for ADR services offered entirely by electronic means, without the need of the disputing parties to leave their homes/offices ${ }^{8}$.

${ }^{6}$ Disponível

$<$ https://www.americanbar.org/content/dam/aba/migrated/dispute/documents/FinalReport102802.p df $>$ Acesso em 18 nov. 2001.

${ }^{7}$ A Consumers International é uma organização de associação de consumidores do mundo inteiro, com representação em 120 países do mundo.

8 Consumers International. Disputes in Cyberspace. Update of online dispute resolution for consumers in cross-border disputes. Apud. KAUFMANN-KOHLER, Gabrielle. SCHULTZ, Thomas. Op. Cit. p. 7. 


\subsection{Um Breve Histórico dos Online Dispute Resolutions}

\subsubsection{O Surgimento dos ODRs}

Muitos autores descrevem o surgimento dos ODRs como tendo passado por 3 grandes fases as quais teriam culminado em uma quarta e atual fase. A primeira delas seria uma fase amadora, na qual alguns interessados pelo assunto começaram a desenvolver de forma amadora soluções digitais para problemas enfrentados por disputas resolvidas por métodos offline. Essa primeira fase teria se iniciado em 1990 e durado até 1996 quando começaram a surgir programas pilotos desenvolvidos por organizações sem fins lucrativos e por instituições acadêmicas, financiados por fundações e órgãos internacionais. A fase que se seguiu se deu entre 1999 e 2000 sendo chamada a fase comercial, durante a qual uma série de companhias passaram a desenvolver e comercializar plataformas privadas de $O D R$. A partir de 2001 teria se iniciado a fase institucional das $O D R s$, na qual uma série de cortes e órgãos oficiais passaram a introduzir e adotar $O D R s^{9}$.

O surgimento dos ODRs foi recebido com grande ceticismo. Isso porque, conforme explica o professor Ethan Katsh, tido como um dos idealizadores das Online Dispute Resolutions, após o surgimento da internet em 1969, durante cerca de vinte a vinte e cinco anos foram poucas as disputas que surgiram em função de seu uso ${ }^{10}$. Assim é que, antes de existir spam, streaming, e-commerce, jogos online, etc... era difícil conceber que a internet

\footnotetext{
9 TYLER, Melissa Coneley. BRETHERTON, Di. Seventy-six and counting: An analysis of ODR sites. In LODDER, Arno R., CLARK, Eugene., GORDON, Thomas. F., KATSH, Ethan, RULE, Colin, THIESSEN, Ernest M., VERHEIJ, Bart, WALTON, Douglas. N, ZELEZNIKOW, John., Essays on legal en technical aspects of Online Dispute Resolution, Amsterdam: CEDIRE, 2004. pp. 13-29. No mesmo sentido, MANIA, Korolina. Online Dispute Resolution: The future of justice. Pedagogical University of Cracow, Institute of Political Science, Poland. Disponível em $<$ https://reader.elsevier.com/reader/sd/pii/S2351667415000074?token=E384493F0DBAF7CF373 AACD80FA6EDF19BC0480A6E8918D09ABCAB549585B8C5E0F0CC4816A23B4BFD566D5 5C07F559B $>$ Acesso em 18 nov. 2001.

${ }^{10}$ Até 1992, era proibido o uso comercial da internet nos Estados Unidos. (KESAN, Jay P., SHAH, Rajiv C., Fool Us Once Shame on You - Fool Us Twice Shame on Us: What We Can Learn From the Privatizations of the Internet Backbone Network and the Domain Name System. Disponivel em ,$<$ https://papers.ssrn.com/sol3/papers.cfm?abstract_id=260834> Acesso em 18 nov. 2001.)
} 
tomaria as proporções que tomou e seria a fonte de tantos conflitos como os que observamos nos dias de hoje $\mathrm{e}^{11}$. Diante da quase inexistência dos conflitos derivados de negócios estabelecidos no ambiente online, era quase impossível se pensar em métodos para solução destes conflitos.

Com o surgimento de browsers amigáveis que facilitavam o uso da internet por leigos, acompanhado de um barateamento do acesso à internet, o ambiente online começou a mudar. Assim, em 1994 a compreensão de que o ambiente cibernético não seria um ambiente necessariamente pacífico começou a ser desenvolvida e com esta compreensão o futuro dos $O D R s$ começou a ser desenhado ${ }^{12}$.

O surgimento de conflitos na web criou o ambiente ideal para o desenvolvimento dos ODRs. Em 1996 foram realizadas as primeiras conferências dedicadas ao estudo dos ODRs, publicados os primeiros artigos em revistas acadêmicas e concedidos os primeiros financiamentos de projetos de $\mathrm{ODR}^{13}$. Em seguida foi criado o Center for Information Technology and Dispute Resolution da Universidade de Massachusetts - que veio a se tornar o National Center of Technology and Dispute Resolution -, dedicado ao desenvolvimento do campo dos ODRs.

As primeiras plataformas de $O D R$ foram desenvolvidas com o objetivo de trazer soluções para os novos problemas que foram surgindo com o rápido crescimento do e-commerce. Em 1995 foram criados dois gigantes do e-commerce: Amazon e eBay e com eles uma série de novas disputas entre seus usuários.

\footnotetext{
${ }^{11} \mathrm{KATSH}$, Ethan. ODR: A look at history. A few thoughts about the present and some speculation about the future. In KATSH, Ethan. WAHAB, Mohamed S. Abdel, RAINEY, Daniel. Online Dispute Resolution: Theory and Practice. A Treatise on Technology and Dispute Resolution. Hague: Eleven International Publishing. pp. 21-22.

${ }^{12}$ Ibid. pp. 21-22.

${ }^{13}$ Ibid. p. 23.
} 
Quatro anos depois de sua criação, o eBay procurou o Amherst Center for Information Technology and Dispute Resolution da Universidade de Massachusetts para que este desenvolvesse um projeto piloto de mediação de disputas entre os vendedores e compradores do eBay. Em apenas duas semanas, o projeto piloto da Universidade de Massachusetts foi responsável pela condução da resolução de 200 disputas o que levou o eBay a passar a prever a possibilidade de resolução de disputas online por seus usuários ${ }^{14}$.

Mas o alcance dos ODRs evoluiu muito desde esse momento inicial, deixando de ser uma ferramenta apenas usada para a solução de conflitos derivados de relações travadas no ambiente online e passando a ser usado na solução de disputas offlines $^{15}$, com o objetivo de simplificá-las e torna-las mais eficientes:

As explained in the first chapter of this book, ODR was initially thought of as a means of redress for disputes that arose online, disputes often between parties in different countries and in which courts and face to face ADR were not feasible. Successes in those disputes led to the use of ODR in traditional offline disputes, sometimes to assist a mediator or arbitrator and sometimes to replace the third party altogether. Today, as 'the digital world merges with the physical world', 3 ODR is moving forward on two tracks. It is building upon and being integrated into familiar dispute resolution processes. It is also generating novel approaches to responding to and preventing conflict, approaches that could not have been developed in a face to face world ${ }^{16}$.

\subsubsection{Porque surgiram os ODRs?}

$\mathrm{O}$ advento da internet possibilitou que as pessoas passassem a trocar informações de forma dinâmica com quem quer que seja nos mais remotos

\footnotetext{
${ }^{14}$ Ibid. p. 27.

15 "Interest in ODR has grown and its focus has expanded. Government agencies, such as the National Mediation Board (NMB) and the Office of Government Information Services (OGIS) in the United States, are adopting and promoting ODR as an effective method of resolving problems with citizens. Government use of ODR promises to be a very large market. eBay is still the most noteworthy ODR effort but there are now others that can be pointed to. Cybersettle, for example, has moved beyond its original focus on insurance disputes and is helping to resolve claims brought against New York City, e.g. pothole disputes. The marketplace for ODR is now offline disputes as well as those originating online and public sector disputes as well as those originating in the private sector". (Ibid. p. 27.)

${ }^{16}$ KATSH, Ethan. WAHAB, Mohamed S. Abdel, RAINEY, Daniel. Op. Cit. p. 3.
} 
pontos do mundo. Essa troca de informações que é cada vez mais rápida, mais segura, de melhor qualidade e mais eficiente teve forte impacto na maneira como nos relacionamos e contratamos: os custos de transação diminuíram e permitiram a realização de contratos mais simples, muitas vezes com objeto de baixo valor e em grande escala, de forma globalizada e sem fronteiras.

Quanto maior o volume dessas contratações, as quais ocorrem desenfreadamente durante todos os segundos do dia, maior o número de disputas a elas relacionadas. Apesar do rápido crescimento dos negócios realizados online, os métodos de resolução de disputas online não se desenvolveram com a mesma rapidez de forma que hoje a maior parte dos litígios ainda é resolvida por meio de métodos tradicionais de resolução de disputa, realizados offline.

Tais métodos tradicionais realizados offline, contudo, muitas vezes não são equipados para resolver esses conflitos adequadamente, seja porque o local da solução da disputa é geograficamente longe, seja porque os custos para acesso àquele método de solução de disputa são muito altos e por vezes superam até mesmo o benefício econômico que poderia ser auferido daquele processo, seja porque o processo para resolução do conflito é moroso demais para as necessidades daquele determinado negócio.

"The result is a vacuum: for many of these disputes no effective resolution mechanism will be available and access to justice is simply not guaranteed. Given that access to justice is considered to be a fundamental human right, this state of affairs is obviously problematic and calls for change"17.

Os ODRs surgem como uma forma de minimizar e, em alguns casos, eliminar os custos decorrentes de ineficiências dos procedimentos realizados em cortes comuns e dessa forma dar efetividade ao direito de acesso à justiça. O relatório anual do Doing Business elaborado pelo Banco Mundial relata

\footnotetext{
${ }^{17}$ KAUFMANN-KOHLER, Gabrielle. SCHULTZ, Thomas. Op. Cit. p. 1.
} 
que a resolução de uma disputa comercial pode demorar até quatro anos e custar até $80 \%$ a mais do que o valor da relação comercial que deu origem ao litígio ${ }^{18}$.

Assim, uma pessoa racional apenas buscaria a tutela jurisdicional caso os custos a ela relacionados fossem menores que os custos objeto da demanda em questão. Isto é, considerando que essa seria uma decisão racional econômica que ignora todos os demais fatores que afastam as pessoas do judiciário, já abordados acima.

A consequência dessa realidade é que uma série de demandas não encontra respaldo no mundo jurídico em função de custos demasiadamente altos em comparação com os valores que buscam discutir.

Essa realidade gera um problema no mundo jurídico uma vez que a grande maioria dos países civilizados estabelece o acesso à justiça como um direito fundamental, desdobrando esse direito em uma obrigação do estado de prover cortes dotadas de praticidade e eficiência a custos acessíveis. Vejase o exemplo da Corte Europeia de Direitos Humanos na análise do caso Golder v. UK:

"It would be inconceivable, in the opinion of the Court, that Article 6 para. 1 (art.
6-1) should describe in detail the procedural guarantees afforded to parties in a
pending lawsuit and should not first protect that which alone makes it in fact
possible to benefit from such guarantees, that is, access to a court. The fair, public
and expeditious characteristics of judicial proceedings are of no value at all if
there are no judicial proceedings.
36. Taking all the preceding considerations together, it follows that the right of
access constitutes an element which is inherent in the right stated by Article 6 para.
1 (art. 6-1). This is not an extensive interpretation forcing new obligations on the
Contracting States: it is based on the very terms of the first sentence of Article 6
para. 1 (art. 6-1) read in its context and having regard to the object and purpose

18 "The efficiency of courts continues to vary greatly around the world. Enforcing a contract through the courts can take less than 10 months in New Zealand, Norway and Rwanda but almost 4 years in Bangladesh. And the cost of doing so ranges from less than $10 \%$ of the value of the claim in Iceland, Luxembourg and Norway to more than $80 \%$ in Burkina Faso and Zimbabwe. In five economies, including Indonesia and Mozambique, the cost can exceed the value in dispute, suggesting that litigation may not be a cost-effective way to resolve disputes". World Bank. Doing Business 2016. Disponível em $<$ https://www.doingbusiness.org/content/dam/doingBusiness/media/AnnualReports/English/DB16-Full-Report.pdf> Acesso 18 Nov. 2019. 
of the Convention, a lawmaking treaty (see the Wemhoff judgment of 27 June 1968, Series A no. 7, p. 23, para. 8), and to general principles of law.

The Court thus reaches the conclusion, without needing to resort to "supplementary means of interpretation" as envisaged at Article 32 of the Vienna Convention, that Article 6 para. 1 (art. 6-1) secures to everyone the right to have any claim relating to his civil rights and obligations brought before a court or tribunal. In this way the Article embodies the "right to a court", of which the right of access, that is the right to institute proceedings before courts in civil matters, constitutes one aspect only. To this are added the guarantees laid down by Article 6 para. 1 (art. 6-1) as regards both the organisation and composition of the court, and the conduct of the proceedings. In sum, the whole makes up the right to a fair hearing. The Court has no need to ascertain in the present case whether and to what extent Article 6 para. 1 (art. 6-1) further requires a decision on the very substance of the dispute (English "determination", French "décidera")"'19.

Os $O D R s$ se apresentam como uma forma de dar efetividade ao direito de acesso à justiça na medida em que diminuem custos do sistema tradicional de resolução de disputas offline. A seguir, vai-se analisar como e em que medida os $O D R s$ reduzem custos.

\subsection{A Redução de Custos Proporcionada pelos ODRs}

Um dos maiores benefícios dos $O D R s$ é que eles reduzem os custos com informação. Isso porque a internet permite que você relacione dados, identifique similaridades em outros casos que possam ser úteis, obtenha feedback de outras experiencia prévias bem como possui uma série de ferramentas que permitem buscas com resultados rápidos e precisos.

Isso faz com que a discrepância informacional entre as partes seja reduzida e, com isso, que as disputas sejam cada vez mais niveladas:

In ODR, information costs are reduced. The Internet facilitates access to information of all kinds, which obviously includes information of a legal nature. The internet impacts on dispute resolution in the sense that it levels the playing field among laymen and more powerful actors; it has an equalizing effect on dispute resolution. To a large extent, this equalizing effect is due to the ease of access to legal information. It has become easier to learn of the existence of similar cases, to draw upon other disputants' experience, and even to join forces in collective actions. One can also more easily locate information on dispute

\footnotetext{
19 Golder v. The United Kingdom. Disponível em: $<$ https://hudoc.echr.coe.int/eng\#\{\%22itemid\%22:[\%22001-57496\%22]\}>Acesso em 18 nov. 2019.
} 
resolution providers (be it small claims courts, or ADR and ODR centers). Legal research is facilitated as well ${ }^{20}$.

ODRs também reduzem custos relacionados a reuniões e audiências. Por meio da utilização de tecnologia de ponta, as partes de uma arbitragem online podem realizar reuniões e até mesmo audiências, sem a necessidade de se encontrarem fisicamente. As implicações disso são enormes, sobretudo com relação aos custos. A realização de reuniões e audiências no ambiente online reduz custos com o deslocamento das partes, de seus advogados, dos árbitros, de testemunhas e de quaisquer terceiros que venham a participar do procedimento, elimina a necessidade de se alugar um lugar para a realização da audiência, facilita a coordenação de agendas, entre outros benefícios.

Deve-se ressalvar, contudo, que a realização de encontros no ambiente online, sobretudo a realização de audiências, não é imune a críticas. Essa forma de procedimento ainda causa estranheza às partes e levanta alguns questionamentos com relação à autenticidade das relações travadas por esse meio $^{21}$.

\footnotetext{
${ }^{20}$ KAUFMANN-KOHLER, Gabrielle. SCHULTZ, Thomas. Op. Cit. p. 75

${ }^{21}$ Vejam se os comentários de Carolina Dzimidas Haber sobre a prova testemunhal tomada por vídeo conferência: "Por mais sofisticados que sejam os meios eletrônicos, somente a presença efetiva na audiência pode assegurar a comunicação entre os sujeitos processuais. Basta lembrar que até mesmo para aferir a sinceridade ou falsidade de uma declaração conta muito a percepção direta e imediata das reações do réu ou da testemunha"(HABER, Carolina Dzimidas. A produção da prova por videoconferência. In Revista Brasileira de Ciências Criminais, 2010).
} 


\title{
3. Blockchain
}

A origem da tecnologia blockchain como é hoje conhecida é atribuída a Satoshi Nakamoto, possivelmente um programador, ou grupo de programadores, cuja identidade e formação é desconhecida. A tecnologia surgiu em outubro de 2008 com a publicação do White Paper denominado "Bitcoin: A Peer-to-Peer Electronic Cash System" como um meio para viabilizar a criação de uma criptomoeda que permitisse às pessoas a realização de pagamentos sem a intermediação de instituições financeiras e de forma segura.

A tecnologia tem um nome bastante ilustrativo uma vez que é uma rede formada por elos de uma corrente - a blockchain - que permitem o armazenamento de todo tipo de informação. O blockchain é como um banco de dados global, referido na literatura estrangeira como um ledger - traduzido livremente como uma livro-razão -, em que podem ser armazenados os mais variados tipos de dados de forma descentralizada. Diferentemente dos bancos de dados tradicionais a que estamos acostumados, no blockchain a informação não é armazenada em um determinado lugar mas sim distribuída por toda a rede, o que impede que se tenha um alvo central de ataque, dando assim mais segurança ao armazenamento da informação. Nas palavras de Don e Alex Tapscott:

\begin{abstract}
Bitcoin or other digital currency isn't saved in a file somewhere; it's represented by transactions recorded in a blockchain kind of like a global spreadsheet or ledger, which leverages the resources of a large peer-to-peer bitcoin network to verify and approve each bitcoin transaction. Each blockchain, like the one that uses bitcoin, is distributed: it runs on computers provided by volunteers around the world; there is no central database to hack. The blockchain is public: anyone can view it at any time because it resides on the network, not within a single institution charged with auditing transactions and keeping records. And the blockchain is encrypted: it uses heavy-duty encryption involving public and private keys (rather like the two-key system to access a safety deposit box) to maintain virtual security ${ }^{22}$.
\end{abstract}

22 TAPSCOTT, Don; TAPSCOTT, Alex. Blockchain Revolution: How the Technology Behind Bitcoin and Other Cryptocurrencies Is Changing the World. Nova York: Penguin, 2016, p. 6-7. 
O blockchain, nas palavras do pseudônimo Satoshi Nakamoto, é uma tecnologia que usa "peer-to-peer distributed timestamp server to generate computational proof of the chronological order of transactions". Esses conceitos são explicados em maior detalhe a seguir.

A rede peer-to-peer, traduzida como uma tecnologia de ponta a ponta, consiste em uma série de nós que são interconectados uns com os outros. Os nós são computadores individuais que possuem cópia de toda a cadeia dos blocos, ou seja, de todos os registros realizados nesse ledger ou livro-razão, assim todas as partes que venham a transacionar com outras partes têm as mesmas informações. Por isso o uso da palavra "peer", as partes são "iguais" nas transações. A transação realizada por meio desta tecnologia é realizada por uma parte diretamente com a outra parte, sem a presença de qualquer intermediário, por isso, "peer-to-peer" 23 .

O problema identificado pelos idealizadores do blockchain é que em transferências realizadas de parte a parte era preciso saber se aquele que está transferindo algo já transferiu aquilo para outra pessoa antes, o chamado gasto duplo.

Tradicionalmente, evita-se o gasto duplo incluindo uma autoridade central de confiança que irá intermediar aquela transação e checar se houve ou não gasto duplo ${ }^{24}$. O blockchain busca justamente eliminar a necessidade dessa autoridade central, eliminando por consequência a dependência que as partes têm nessas autoridades para efetuarem suas respectivas transações e permitindo a elas transacionar sem a necessidade de qualquer confiança de parte a parte. Assim, tornou-se necessário encontrar uma solução para tal problema.

\footnotetext{
${ }^{23}$ NAKAMOTO, Satoshi. Bitcoin: A Peer-to-Peer Electronic Cash System. Disponível em: $<$ https://nakamotoinstitute.org/bitcoin/> Acesso em 18 nov. 2019

${ }^{24}$ Ibid.
} 
A solução encontrada por Nakamoto ao gasto duplo é de dar grande publicidade às transações sob o raciocínio de que "a única maneira que se pode confirmar a ausência de uma transação é estando ciente de todas as transações" 25 . Assim, cada vez que ocorre uma transferência esta é registrada como um bloco na blockchain por meio de uma chave pública - que serve para a identificação do usuário no sistema - e uma chave privada - que funciona como uma espécie de senha privada que permite a validação da atuação do usuário no sistema. A chave pública permite que todos os computadores da rede tenham um registro atualizado de todas as transações da rede, impedindo eventuais fraudes.

Nessa linha, o sistema criado pelos programadores permite que, ao se dar publicidade a todas as transações realizadas, todos os nós integrantes do sistema possam eles mesmos conferir quais transações foram realizadas pela primeira vez. Assim a validade de determinada transação depende que a maioria dos nós do sistema concordem que aquela transação foi a primeira, invalidando as posteriores.

O sistema que tornou isso possível foi o denominado timestamp server que pode ser traduzido livremente como impressão digital única. A partir desse sistema, toda vez que determinado dado é imputado ele recebe um código digital, conhecido como $h a s h^{26}$, com um carimbo temporal que marca o momento da transação. Esse hash é em seguida amplamente publicado no sistema. Todo novo código digital gerado com carimbo temporal inclui os

\footnotetext{
${ }^{25} \mathrm{Ibid}$

26 "In simple terms, hashing means taking an input string of any length and giving out an output of a fixed length. In the context of cryptocurrencies like bitcoin, the transactions are taken as an input and run through a hashing algorithm (bitcoin uses SHA-256) which gives an output of a fixed length. (...) As you can see, in the case of SHA-256, no matter how big or small your input is, the output will always have a fixed 256-bits length. This becomes critical when you are dealing with a huge amount of data and transactions. So basically, instead of remembering the input data which could be huge, you can just remember the hash and keep track". Block Geeks. What is Blockchain Technology. Disponível em <https://blockgeeks.com/guides/what-is-blockchain-technology/> Acesso 18 Nov. 2019
} 
códigos digitais com os carimbos temporais anteriores, formando uma cadeia cronológica das transações que é reforçada a todo tempo com cada carimbo temporal adicional.

Ao criar essa cadeia de blocos interligados que possuem os dados de todos os hash anteriores, o blockchain criou uma tecnologia muito segura de armazenar dados em função do "proof of work", traduzido livremente como prova do trabalho. Isso porque, os novos blocos são sempre adicionados à cadeia maior e qualquer um que tente modificar, ainda que minimamente, determinado bloco acarretará mudanças em todos os blocos anteriores daquela cadeia. Assim, para se alterar um bloco seria necessário refazer todo o trabalho da cadeia, o que é praticamente impossível de se fazer.

É possível ver com isso que o blockchain funciona como uma forma muito segura de se armazenar dados, algo que é bastante interessante para o mundo das arbitragens, sobretudo considerando a frequência com que se determina a confidencialidade dos procedimentos. 


\section{A Companhia JUR}

\subsection{A Companhia e sua proposta}

A JUR é uma companhia Suíça que, a partir da crise financeira de 2008, começou a notar uma mudança na sistemática dos escritórios de advocacia. Se por um lado os clientes estavam atrás de trabalhos mais complexos, de melhor qualidade e ao menor preço possível, de outro os escritórios encontravam dificuldades para atender a tais demandas bem como falhavam em assegurar uma boa qualidade de vida para seus advogados ${ }^{27}$.

Os escritórios enfrentam ainda a competição com produtos tecnológicos voltados para o mercado legal que ameaçam reduzir a necessidade de advogados em função de uma maior automação de questões operacionais. Vejam-se abaixo as consequências vislumbradas pela Companhia para tal situação:

If not correctly addressed, this situation could degenerate: on the one hand, the job market for lawyers could suffer a drastic contraction, since working for law firms appears less and less attractive and at high risk of success given the potential reduction in demand for traditional legal services; on the other hand, companies would make a serious underestimation mistake in believing that lawyers can be completely replaced, that everything can be automated, without taking into account the high risk of exposure to litigation ${ }^{28}$.

A Companhia enxerga na inteligência artificial uma forma de otimizar tanto a criação dos contratos como sua execução e a resolução de eventuais conflitos. A partir de uma automatização de tudo que permite automatização seria possível reduzir custos e tornar mais acessíveis todas as etapas envolvidas em uma relação contratual.

\footnotetext{
${ }^{27}$ The balance seems on the verge of breaking down as the biggest law firms fail to ensure a good work-life balance for their lawyers, companies are demanding more and more at low cost, and the emergence of legal tech products threatens to replace lawyers with software based on the automation of certain operational processes (JUR. White Paper. Disponível em: <https://jur.io/wpcontent/uploads/2019/05/jur-whitepaper-v.2.0.2.pdf> $>$ Acesso 18 Nov. 2019).

${ }^{28}$ Ibid.
} 
A JUR se utiliza da tecnologia de blockchain para "transformar essa automação em realidade" 29 . Com base nessa tecnologia, a JUR está desenvolvendo uma plataforma, ainda não operacional, que busca a automação - na medida do possível ${ }^{30}$ - de todas as fases contratuais, oferecendo produtos para a facilitação de cada uma dessas fases, são eles:

- "the "Jur Platform", a platform for the creation and sale of "Smart Legal Contracts", which are fully customizable contracts. With Jur's easy-to-use interface, the user can select and assemble contract elements that contain both the necessary computer code and accompanying legal language. Hence, the resulting technological product is a truly "smart" and truly "legal" contract. The Jur Platform consists of:

- the "Jur Editor" allows users to create Smart Legal Contracts either starting from a blank document or using templates made available by other users;

○ the "Jur Marketplace", facilitates the sale of smart legal contract templates created by users of this platform;

- $\quad$ three innovative dispute resolution mechanisms graduated in complexity according to the value of the disputes, which aim to create real jurisdictions on the blockchain, namely:

○ the "Court Layer", digitized commercial arbitration which renders arbitration awards that are binding and fully recognizable and enforceable under the New York Convention, designed for high-value disputes;

○ the "Open Layer", an online dispute resolution mechanism where the decision-making process is open to all participants through game theoretic principles, mostly suited for low-value disputes;

- the "Community Layer", an online dispute resolution mechanism where only experts who are members of the community selected by the parties can participate in the decision-making process, designed for medium value disputes".

Conforme já explicado no Capítulo I, o presente trabalho terá como foco o "Court Layer" acima mencionado o qual, de maneira resumida, é uma forma de arbitragem digital.

\subsection{O "Court Layer"}

Conforme já explorado no Capítulo 2 acima, as $O D R$ s surgiram muito em função da necessidade de desenvolver métodos de resolução de conflitos

\footnotetext{
29 Ibid.

30 A JUR reconhece que determinadas questões, sobretudo as de maior complexidade, não comportam uma resolução de conflitos totalmente automatizada. Contudo, ainda com relação a essas questões, é possível se valer da tecnologia blockchain para incrementar a arbitragem tradicional.
} 
que fossem capazes de atender de forma adequada às novas necessidades surgidas no âmbito do e-commerce. Essas disputas relacionadas ao $e$ commerce são, em sua grande maioria, disputas menores e menos complexas que envolvem valores relativamente baixos.

O Court Layer desenvolvido pela JUR vai além dos produtos tradicionais do $O D R$ voltados para o e-commerce e busca oferecer uma verdadeira "smart arbitration", voltada para disputas de maior complexidade e com valores relevantes envolvidos ${ }^{31}$. O produto oferecido pela JUR busca, por meio do uso de tecnologia blockchain, (i) reduzir custos por meio da padronização de processos; (ii) reduzir o tempo de duração dos procedimentos por meio de uma maior eficiência da administração; e (iii) facilitar o acesso das partes uma vez que todo o procedimento é realizado online.

O Court Layer tem ainda por objetivo oferecer os meios para garantir um processo decisório de maior qualidade que tem como foco (i) uma escolha imparcial dos árbitros; (ii) um sistema de avaliação e revisão das decisões pelos pares; (iii) um mecanismo diferenciado para pagamento dos árbitros; (iv) a recompensa de árbitros bem avaliados por seus pares; e (v) um sistema de responsabilidade dos árbitros, câmaras e revisores baseado na reputação destes. Todos esses elementos que compõem o Court Layer serão analisados em maior profundidade a seguir.

\subsubsection{Os Arbitration Hubs}

O Court Layer consiste de uma série de Arbitration Hubs que são espécies de órgãos arbitrais institucionais, ou entidades especializadas de

\footnotetext{
31 "The Court Layer combines some of the benefits of decentralization, blockchain technology, and digitization in general, with traditional arbitration mechanisms. By doing so, Jur provides a form of "smart arbitration" that ensures complete legally binding decisions that are suitable for highly complex disputes over large sums, and achieves this in an affordable way". (JUR. White Paper.

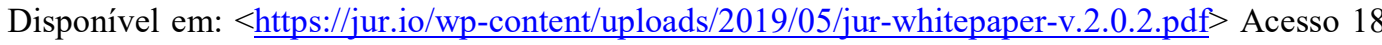
Nov. 2019)
} 


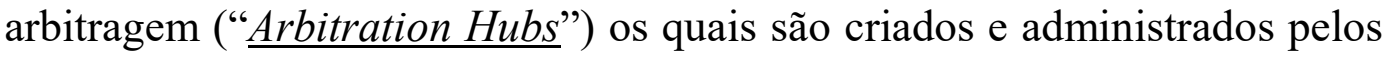
$H u b$ Admins, que por sua vez são as próprias instituições que desejam oferecer um órgão arbitral (" $\mathrm{HubAdmins").}$

Para a criação de um Arbitration Hub, o Hub Admin deve estabelecer as regras de sua criação e funcionamento, as quais devem observar os princípios gerais do Court Layer ("Hub Rules") ${ }^{32}$.

Ao criar um Arbitration Hub, o Hub Admin deve também criar uma espécie de fundo de garantia de desempenho, o qual será formado por JUR Tokens $^{33}$, que são uma espécie de moeda utilizada no ecossistema do JUR ("Fundo de Garantia"). Essa garantia de desempenho deve ser proporcional ao valor máximo envolvido em disputas que o Arbitration Hub aceita administrar, e serve como uma forma de garantir decisões de qualidade e livres de eventual corrupção ${ }^{34}$.

Uma vez constituído o Arbitration Hub, ele terá que então se equipar de um corpo de árbitros, os quais são escolhidos na forma descrita no Capítulo 4.2.2. abaixo. Todas as disputas do Court Layer são decididas ou por árbitro único ou por um tribunal arbitral composto por três árbitros ${ }^{35}$. A recomendação da JUR é que as disputas que envolvam valores inferiores a 150.000,00 USD sejam resolvidas por árbitro único, e as disputas que

\footnotetext{
${ }^{32}$ O JUR disponibiliza um set de Hub Rules padrão que pode ser adaptado por cada Hub Admin. 33 “JUR Token, according to our FINMA non-action letter, is a hybrid token that has both utility token characteristics and payment token characteristics. The JUR Token is the token on which the ecosystem is based. However, users can use fiat currencies and stablecoins for payment. When they do so, a conversion in JUR Tokens occurs, except in the case of stablecoin escrow deposits. Such a conversion is automatic and "invisible" to the user, thanks to a user-friendly interface". (JUR. White Paper. Disponível em: <https://jur.io/wp-content/uploads/2019/05/jur-whitepaper-v.2.0.2.pdf $>$ Acesso 18 Nov. 2019)

34 "The Hub Admin creates the Arbitration Hub by staking JUR Tokens. This amount of JUR Token constitutes a kind of guarantee fund, hereinafter referred to as the "Performance Bond", which serves to guarantee the parties to the dispute that the Arbitration Hub is able to render corruptionfree high-quality decisions. The amount of the required Performance Bond is proportional to the maximum dispute value accepted by the Arbitration Hub" (Ibid.)

35 "Once the Arbitration Hub is established, it will have to equip itself with arbitrators. Arbitration disputes in the Court Layer can be decided by a sole arbitrator or by an arbitral tribunal composed of three arbitrators". (Ibid.)
} 
envolvam valores superiores a esse patamar sejam resolvidas por um painel arbitral de 3 árbitros ${ }^{36}$.

\subsubsection{Hub Rules}

\section{A) A Seleção de Árbitros}

Ao estabelecerem as regras relativas ao Arbitration $\mathrm{Hub}$, os $\mathrm{Hub}$ Admin devem estabelecer como será feita a seleção do seu corpo de árbitros que resolverão as disputas submetidas ao Arbitration Hub. Para tanto, os Hub Admins deverão escolher um de dois métodos para o processo seletivo de árbitros, quais sejam:

(i) Seleção Centralizada: o Hub Admin estabelece as regras e critérios para recrutar árbitros e ele mesmo organiza a seleção; ou (ii) Seleção Descentralizada: o Hub Admin apenas define critérios e requisitos objetivos que os árbitros devem preencher. Assim, qualquer pessoa que tenha interesse em ser árbitro deverá enviar seu requerimento de candidatura ao Hub Admin e apostar JUR Tokens. A avaliação desse requerimento será então delegada ou ao Open Layer ou ao Community Layer do JUR, de acordo com o que for estabelecido pelo Hub Admin nas Hub Rules. A avaliação será então reconhecida pelo sistema como sendo uma disputa muito simples em que os participantes serão perguntados apenas se aceitam ou não o requerimento do candidato a árbitro.

\footnotetext{
36 "The sole arbitrator is ideal for disputes up to 150,000 USD equivalent, while for higher disputes an arbitral tribunal composed of three arbitrators is recommended. For these reasons, each Arbitration Hub must be able to count on an adequate number of potential selectable arbitrators". (Ibid.)
} 
Com relação ao método descrito no item (ii) acima, cumpre explicar de forma breve o que são e como funcionam o Open Layer e o Community Layer do JUR.

Open Layer

O Open Layer é um dos serviços oferecido pela JUR para a solução de disputas. Distinto do Court Layer que busca apenas automatizar os já tradicionais procedimentos arbitrais, o Open Layer é um mecanismo de resolução de disputas que usa a tecnologia blockchain para oferecer uma decisão descentralizada para disputas pequenas e simples, de forma rápida e barata.

A partir de um sistema de incentivos econômicos baseados em game theory, os participantes devem, de forma binária, votar em uma de duas opções para resolução daquele conflito e devem dar peso aos seus respectivos votos apostando JUR Tokens. As opções em que os participantes devem votar são fornecidas pelas partes da disputa, que devem propor a solução que lhes parece mais justa para aquele conflito. A opção na qual os participantes tenham apostado mais dinheiro é a opção vencedora e a parte que a propôs ganha a disputa ${ }^{37}$.

\footnotetext{
37 “The Open Layer (patent pending) uses a system of economic incentives based on game theory to motivate voters to choose between two options and give weight to their vote by staking tokens, expressing the stake-weighted wisdom of the crowd in the form of a simple binary decision Proposal A, or Proposal B? The result is determined by the amount of JUR staked on each proposal rather than a per capita vote. This innovative approach does not qualify as a legal judgment, but it is fair, fast, free and if you attach it to a Jur Smart Legal Contract with an escrow, the judgment is executed as soon as it is made (as little as 24 hours) so there is no need to pursue payment in court. The parties must each propose a resolution to the dispute. Rational actors will make proposals that they believe will be seen as the most fair of the two choices. Note that a rational party will not necessarily propose what they think is fair. They may propose an option designed to unfairly favor their interests, as long as it is less unfair than the counterparties proposal. For instance, if Bob thinks splitting the escrow 50/50 between Bob and Alice is fair, but he thinks Alice will propose 10/90, Bob might propose 80/20". (Ibid)
} 


\section{Community Layer}

O Community Layer é o terceiro e último sistema de resolução de disputas oferecido pelo JUR. Este sistema é muito parecido com o Open Layer, acima descrito, com a diferença que o Community Layer limita quem pode votar e apostar naquela disputa, buscando selecionar pessoas mais especializadas e qualificadas que tenham capacidade de resolver disputas mais complexas do que aquelas resolvidas pelo Open Layer ${ }^{38}$.

Assim, para a escolha do corpo de árbitros que integrarão o seu Arbitration Hub, o Hub Admin deve ou estabelecer as regras para o processo seletivo que ele mesmo conduzirá ou deve estabelecer parâmetros e critérios que devem ser preenchidos, submetendo o requerimento do candidato a árbitro como uma espécie de disputa simples em um dos dois ambientes descritos acima.

Quando o Arbitration $H u b$ recebe uma disputa há uma seleção aleatória dentro do corpo arbitral que compõe aquele $H u b$ específico do árbitro ou tribunal arbitral responsável pela resolução daquela determinada disputa. Os critérios e parâmetros escolhidos pelo Hub Admin são públicos de forma que as partes podem analisar se determinado Arbitration Hub se adequa às suas respectivas necessidades de acordo com as qualificações que são exigidas dos profissionais que integrarão aquele corpo arbitral. Assim, de forma diferente da maior parte das arbitragens tradicionais offline, as partes não escolhem os árbitros específicos que atuarão na resolução de sua disputa, escolhendo apenas o corpo arbitral que mais se adequa às necessidades daquela disputa.

\footnotetext{
38 " 1 . The system is designed for disputes of medium complexity and value, and to issue decisions in an estimated minimum time of 24 hours to an estimated maximum of 1 week. 2. The disputes are decided by voters according to incentives and voting mechanisms that are largely the same as the Open Layer (the voting mechanism of both these ODRs is based on the same pending patent by Jur). 3. The vote is not open to everyone, but rather only to communities of selected voters. (...)" (Ibid)
} 


\section{B) Procedimento}

A JUR oferece três tipos de procedimentos padronizados que devem ser pré selecionados pelas partes ou pelos árbitros a depender da complexidade e dos valores envolvidos na disputa em questão, quais sejam:

(i) Arbitragem Documental: é a forma mais rápida de condução de uma arbitragem e não prevê a possibilidade de realizar audiências ou de ouvir testemunhas. Em função dessa limitação, os custos relativos a este procedimento são geralmente muito baixos e as decisões proferidas de forma muito célere. Apesar de os Hub Admins terem liberdade para estabelecer seus respectivos custos de procedimento e cronogramas procedimentais, a JUR estima que disputas de menor complexidade submetidas ao procedimento da Arbitragem Documental devem durar, no máximo dois meses e custar, no caso de árbitro único, entre 700,00 e 1.300,00 euros, a depender dos valores envolvidos;

(ii) Arbitragem Rápida: neste tipo de procedimento, a arbitragem fica limitada a apenas duas audiências, com apenas duas testemunhas por parte. A JUR estima uma redução de até $30 \%$ dos custos incorridos com uma arbitragem tradicional offline e uma duração de aproximadamente três meses para a resolução da disputa.

(iii) Arbitragem Comum: neste tipo de procedimento não há limitações quanto ao número de audiências ou de testemunhas a serem ouvidas. Este tipo de procedimento é recomendável para disputas de maior complexidade, envolvendo valores acima de 150.000,00 euros. Recomenda-se que essas disputas sejam resolvidas por um tribunal composto por três árbitros e estima-se que os custos devem ser de no 
mínimo 6.000,00 euros e a duração do procedimento varia de três a quatro meses. ${ }^{39}$

A JUR dá aos Hub Admins, observados os limites já mencionados acima, liberdade para estabelecer suas próprias regras, cronogramas, custos de procedimento, valor do Fundo de Garantia, entre outras regras, da forma que acharem mais adequada. Com isso, a JUR busca criar competitividade entre os Arbitrations Hubs para oferecer procedimentos online de maior eficiência ${ }^{40}$.

Os Hub Rules deverão prever de forma mais detalhada como será esse procedimento, estabelecendo o número de manifestações que poderão ser apresentadas pelas partes, a possibilidade de realização de audiências, a produção de provas etc. Todas essas etapas do procedimento serão realizadas online e arquivadas no blockchain que, por sua vez, funcionará como uma espécie de cartório.

\subsubsection{Sentença}

Ao fim do procedimento, o tribunal arbitral analisará as manifestações das partes e as provas produzidas ao longo do procedimento e com isso minutará sua decisão. Como uma forma de garantir decisões de maior qualidade e confiabilidade, a JUR desenvolveu um sistema de revisão das decisões arbitrais que funciona da forma descrita abaixo.

\footnotetext{
39 "1. Documentary Arbitration: the fastest form of arbitration does not provide for hearings or witnesses. For this reason, the costs, in general are very low. As an example, considering a $€ 10,000$ value dispute, the total cost of arbitration may be between $€ 700$ and $€ 800$ in the case of a single arbitrator. For a dispute of $€ 25,000$ in the case of a single arbitrator between $€ 800$ and $€ 1300$. The time for resolving disputes of minor complexity will be less than two months in the worst case scenario. 2. Quick Arbitration: this form is limited to two hearings maximum and a maximum of two witnesses per party with a cost reduction up to $30 \%$ compared to ordinary arbitration and a time limit of about three months. 3. Ordinary Arbitration: in general, for a dispute over $\epsilon$ 150,000 or more, the costs for a panel of three arbitrators may start at $€ 6,000$. Here the arbitration can take up to 3 or 4 months, depending on the number of witnesses and complexity of the subject". (Ibid.) ${ }^{40}$ Ibid.
} 
Antes de ser proferida uma sentença final, os árbitros submetem a minuta de sentença por eles elaborada à avaliação de três de seus pares, que serão selecionados de forma aleatória dentro do ambiente do JUR, são os chamados peer-reviews ("Peer Reviewers").

Os Peer Reviewers então analisam a minuta de sentença a eles submetida e conferem à minuta uma nota. Essa nota tem dois efeitos: primeiro de passar a incorporar um sistema de avaliação reputacional dos árbitros de forma a alimentar o sistema com um feedback acerca da qualidade do trabalho realizado por aqueles árbitros; segundo de definir se aquela minuta de sentença será transformada em uma sentença definitiva ou se aquela minuta será objeto de revisão.

Caso a avaliação da sentença seja positiva de uma forma geral, aquela minuta proposta pelo tribunal arbitral será transformada em sentença definitiva. Caso, por outro lado, a avaliação seja negativa, o procedimento será realocado pelo sistema da JUR a novos árbitros, que serão responsáveis pela elaboração de uma nova sentença.

A nova sentença também será submetida à análise dos Peer Reviewers mas dessa vez apenas para fins do descrito no item (i) acima a nova sentença não será, portanto, objeto de uma nova realocação ainda que sua avaliação seja negativa. Os custos relacionados à realocação do procedimento a novos árbitros serão cobertos pelo fundo de garantia do Arbitration $\mathrm{Hub}^{41}$.

\footnotetext{
41 "The peer reviewers express their evaluation by assigning a score to the provisional draft of "arbitral award" - the normal term for the decision resulting from arbitration. Subsequently, such scores are incorporated into a reputation system that ensures high-quality arbitrators. If the peer review is positive overall, the provisional draft proposed by the arbitrators will become the final and binding arbitral award. If the peer review is negative overall, the dispute will be reassigned by the system to new arbitrators, who will issue a new decision. This second decision will be submitted to the peer review mechanism for the sole purpose of assigning a score to the decision, and therefore in order to give new input to the reputation system that tracks the work of the arbitrators. A second reassignment of the dispute to new arbitrators will not be allowed. Costs for such proceedings shall be covered with funds from the Performance Bond". (Ibid.)
} 
Os Peer Reviewers são remunerados em JUR Tokens com base em um sistema de remuneração desenvolvido a partir da teoria dos jogos. Os Peer Reviewers receberão ou perderão JUR Tokens a depender da proximidade da nota por eles atribuída à minuta de sentença com a média da nota atribuída por todos os três Peer Reviewers. 


\section{A plataforma do Court Layer da JUR à luz da Lei de Arbitragem Brasileira}

Como se viu acima, o Court Layer da JUR se propõe a prover um ambiente em que possam ser realizados procedimentos arbitrais conduzidos inteiramente online. Para avaliar a adequação desse modelo de arbitragem inovador à nossa legislação pátria parece importante analisar detidamente as características e requisitos obrigatórios que devem ser observados para que o procedimento arbitral seja válido e eficaz no Brasil. É o que se passa a fazer.

\subsection{Arbitragem e a Autonomia da Vontade das Partes}

A arbitragem é um método de resolução de conflitos privado por meio do qual são conferidos poderes a uma ou mais pessoas para decidirem a controvérsia em questão, sem intervenção estatal mas com força de sentença judicial. Como se verá em mais detalhe mais a frente, tais poderes emanam de uma convenção privada e a controvérsia deve ser decidida com base em tal convenção ${ }^{42}$.

A Lei de Arbitragem estabelece que as partes que escolham a via arbitral para dirimir suas controvérsias têm ampla liberdade para escolher o direito aplicável à controvérsia, sendo ele material ou processual. Tamanha é a liberdade conferida às partes que Lei de Arbitragem faculta ainda que estas pactuem que seus conflitos serão resolvidos por equidade, algo que não é possível de ser feito pelo judiciário, por exemplo.

Assim, tem-se que em sede de arbitragem o princípio da autonomia da vontade tem enorme prestigio, devendo ser observado em todo o procedimento:

\footnotetext{
${ }^{42}$ CARMONA, Carlos Alberto. Arbitragem e Processo - Um comentário à Lei 9.307/96. São Paulo: Editora Atlas, 2004. p. 33.
} 
Prestigiou-se em grau máximo e de modo expresso o princípio da autonomia da vontade, de forma a evitar dúvidas na aplicação da lei. Sabe-se que no Brasil o princípio da autonomia da vontade encontra alguma dificuldade em sua aplicação, afirmando Irineu Strenger que o princípio foi abandonado pela Lei de Introdução do Código Civil, porque 'dava margem a muita controvérsia, a muita discussão'. Em sede de arbitragem, porém, muitos problemas são resolvidos com a expressa escolha da lei aplicável pelas próprias partes, de tal sorte que o árbitro não terá que recorrer às regras conflitos de leis para estabelecer a norma que regerá o caso concreto. Faz-se mister frisar que as 'regras de direito', a que se refere o art. $2^{\circ}, \S 1^{\circ}$, são tanto de direito material quanto processual: quanto às regras de direito processual, nada impede que as partes criem normas especificas para solucionar o litígio, reportem-se às regras de um órgão arbitral institucional ou até mesmo adotem as regras procedimentais de um código de processo civil estrangeiro ${ }^{43}$ ".

Tal princípio não está limitado à escolha do direito aplicável, sendo na verdade conforme explica Selma Lemes, da própria essência do instituto da arbitragem, encontrando "na instituição e auto regulamentação da arbitragem sua plena aplicação, limitado apenas pelas leis imperativas nacionais e regras de ordem pública"44.

Quando as partes optam pela via arbitral elas passam a ter ampla liberdade para "convencionar livremente com a outra parte as regras aplicáveis ao procedimento arbitral, lei aplicável (quando for o caso), escolha e número de árbitros, local da arbitragem, concessão para resolver por equidade" 45 e todos os outros aspectos relativos ao procedimento, observados os limites da lei e das regras de ordem pública.

\section{É nesse sentido que Fredrick E. Sherman define o instituto da} arbitragem como sendo "a creature of contract" em que as partes têm ampla liberdade para ditar o procedimento que será adotado:

As arbitration is a creature of contract, the parties may give the arbitrators only such powers as they wish them to have and may dictate the way in which the arbitrators make their decisions. Already mentioned examples of such tailoring are the imposition of time limits and setting procedural rules for the hearing or not hearing witnesses and for discovery procedures. Requiring or absolving the

\footnotetext{
${ }^{43}$ Ibid. p. 34.

${ }^{44}$ LEMES, Selma M. Ferreira. Arbitragem. Princípios Jurídicos Fundamentais. Direito Brasileiro e Comparado. In. Revista dos Tribunais. vol 686, 1992. pp. 73-89.

${ }^{45}$ Ibid. p. 35
} 
arbitrators from the obligation to render a reasoned written opinion would be another example $(. . .)^{46}$.

A partir do acima exposto tem-se que, ao analisar a compatibilidade do Court Layer da plataforma JUR com o ordenamento jurídico brasileiro, esta deve ser realizada a partir do princípio da autonomia das partes, buscando se prestigiar a liberdade das partes no procedimento arbitral.

\subsection{A Convenção de Arbitragem}

Conforme dispõe o art. $3^{\circ}$ da Lei de Arbitragem, as partes podem submeter seus conflitos à arbitragem por meio da convenção de arbitragem que é "um acordo de vontades pelo qual as partes se vinculam à solução de litígios determinados ou determináveis, presentes ou futuros, por meio de juízo arbitral, sendo derrogada em relação aos mencionados litígios a jurisdição estatal" ${ }^{\prime \prime}$. A convenção, por sua vez, poderá ser na forma de uma cláusula compromissória ou de um compromisso arbitral, conforme arts. $4^{\circ} \mathrm{e}$ $9^{\circ}$ da Lei de Arbitragem.

O compromisso arbitral é verificado quando as partes decidem pela instituição do procedimento arbitral, em prejuízo da jurisdição estatal, quando o litígio já existe. Isto é, as partes ao verificarem a existência de um conflito pactuam que este será solucionado por meio de um procedimento $\operatorname{arbitral}^{48}$. Já a cláusula compromissória antecede o conflito, e é a forma pela qual as partes estabelecem que eventuais conflitos surgidos no bojo de determinada relação serão resolvidos pela via arbitral ${ }^{49}$.

\footnotetext{
${ }^{46}$ SHERMAN, Fredrick E. Sophisticated Arbitration. In. Arbitragem Interna e Internacional. Questões de Doutrina e da Prática. Coord. Ricardo Ramalho Almeida. Rio de Janeiro: Renovar, 2003. pp. 58-59.

${ }^{47}$ GUERRERO, Luiz Fernando. Convenção de arbitragem e processo arbitral. São Paulo: Editora Atlas, 2009. p. 5.

${ }^{48}$ BRAGHETTA, Adriana. Cláusula Compromissória - autossuficiência da cláusula cheia. In Doutrinas Essenciais Arbitragem e Mediação, 2014. pp. 33-42.

${ }^{49}$ Ibid. pp. 33-42.
} 
Essa distinção tinha mais importância antes da vigência da Lei da Arbitragem de 23 de setembro de 1996. Como explica Luiz Fernando Guerrero, a cláusula compromissória possuía natureza jurídica de um précontrato no antigo regime o que lhe tirava a força vinculatória uma vez que seria necessária a celebração de um compromisso arbitral para que a arbitragem fosse instituída. Tal fato representava um grande obstáculo ao instituto da arbitragem porque exigia que as partes, após já terem um conflito instaurado entre si e muitas vezes após já terem até mesmo cessado os canais de comunicação e de negociação, celebrassem de comum acordo o compromisso arbitral.

Tal questão ficou superada pela de Lei de $\operatorname{Arbitragem~}^{50}$ na medida em que passou a permitir a instituição da arbitragem diretamente pela parte interessada, mesmo nas situações em que uma das partes oferecesse resistência quanto à sua instituição, desde que presentes alguns requisitos na cláusula compromissória. A clausula compromissória que contenha todos os elementos necessários à instauração direta da arbitragem é conhecida como a cláusula cheia.

A força dada à clausula compromissória foi ainda reafirmada no art. $7^{\circ}$ da Lei de Arbitragem que passou a prever que, na ausência de certos requisitos da cláusula compromissória e frente a uma parte recalcitrante, a negativa da parte pudesse ser substituída por uma sentença. Neste caso, estáse diante de uma cláusula vazia.

Deve-se ressaltar, contudo, que as cláusulas vazias, devem ser a exceção. As partes devem redigir suas cláusulas compromissórias de forma

\footnotetext{
${ }^{50}$ O que se conclui é que a convenção de arbitragem é a forma pela qual se institui o juizo arbitral, sendo suas duas espécies modos distintos de visualização do mesmo fenômeno, ou seja, obrigatoriedade ou vinculação das partes à arbitragem, sem que haja diferença fundamental de objetivo ou de eficácia entre estas espécies. (GUERRERO, Luiz Fernando. Op. Cit. p. 10.)
} 
a permitir a instauração da arbitragem, sem que seja necessária a judicialização da matéria:

Deve-se também permitir que o acordo das partes produza efeitos imediatamente $e$, nesse sentido, a convenção deverá conter, como regra, os elementos necessários para que a arbitragem tenha início sem a necessidade de outro acordo de vontade entre as partes. A exceção é a convenção que não contenha todos os elementos necessários para o início da arbitragem. ${ }^{51}$

Nesse sentido, é que o procedimento previsto pelo art. $7^{\circ}$ da Lei de Arbitragem é excepcional, devendo ser instaurado tão somente quando se estiver diante de uma cláusula arbitral vazia e não for possível celebrar de comum acordo um compromisso arbitral que preencha suas lacunas:

Todavia o recurso ao judiciário para a celebração do compromisso arbitral limitase aos casos em que a cláusula arbitral não contém todos os elementos para a instituição do juízo arbitral; é a chamada cláusula em branco ou vazia. A cláusula cheia prescinde de compromisso porque já contém todos os requisitos para a instituição do juízo arbitral ${ }^{52}$.

Como já se viu acima, o princípio da autonomia da vontade das partes é um dos corolários do instituto da arbitragem, devendo ser observado a todo tempo no procedimento. Nesse sentido, as partes têm ampla liberdade para estabelecer convenções de arbitragem dos mais variados tipos, escolhendo de comum acordo as regras e estruturas que melhor se adequam às suas necessidades. Nesse momento, as partes alinham seus interesses e colaboram para fins da elaboração de uma cláusula compromissória que permita a elas se utilizarem da arbitragem se e quando da ocorrência de conflitos.

A posição das partes ao celebrarem a cláusula compromissória é de partes em
colaboraçáo. O que ambas buscam, nesse momento, é criar um mecanismo que
seja aplicável à solução de suas controvérsias, se e quando estas venham a surgir.
Portanto, do ponto de vista da conclusão da cláusula compromissória, estariam as
partes alinhadas com o princípio da boa-fé objetiva. Há inerente na conclusão da
cláusula compromissória o traço da colaboração entre as partes signatárias, da
identidade de propósitos, qual seja, o de utilizarem-se da arbitragem quando

${ }^{51}$ Ibid. p. 13.

${ }^{52}$ BRAGHETTA, Adriana. Op. Cit. P. 33-42. 
venham a surgir suas controvérsias, sem mencionar a sua integração na equação de equilíbrio econômico do contrato ${ }^{53}$.

Assim, como explica José Emílio Nunes Pinto as partes devem sempre evitar a edição de cláusulas vazias de forma a prestigiar a autonomia da vontade, permitindo que se respeite a intenção das partes à época da celebração da cláusula compromissória:

\begin{abstract}
No entanto, o art. $7 .^{\circ}$ da Lei 9.307/1996 se destina a regular a instituição da arbitragem que se funde em "cláusula vazia" ou em "cláusula patológica"; mas esse dispositivo foi criado para regular situações excepcionais ou anômalas, sendo dever dos operadores do direito zelar para que a incidência de cláusulas dessa natureza seja cada vez menor. Isso significa que precisão e clareza são elementos fundamentais na elaboração de cláusulas compromissórias. Dessa forma, e somente dessa forma, estaremos assegurando que a expectativa das partes se materialize efetivamente. Vale a pena registrar, quanto a essa materialização de expectativas, a importância do dever acessório de proteção, este decorrente do princípio da boa-fé objetiva, desdobrando-se na confiança que deve estar presente na relação obrigacional e expressão da lealdade que deve presidir as relações negociais, ou seja, a confiança de se ver materializado aquilo que se previu na etapa contratual como adequado e desejável para a solução de controvérsias. Nessa mesma linha de idéias, não se pode esquecer a excepcionalidade outorgada ao recurso ao contencioso previsto no art. $7 .^{\circ}$ da Lei 9.307/1996, já que se espera que as partes, diante de uma cláusula vazia ou patológica, colaborem mutuamente no sentido de suprir as deficiências existentes na cláusula compromissória, viabilizando a instituição da arbitragem e respondendo efetivamente à expectativa que determinou a escolha de ambas quando da celebração do contrato e da respectiva convenção ${ }^{54}$.
\end{abstract}

Para que as partes que tenham pactuado a condução de um procedimento arbitral online no ambiente JUR tenham sua intenção respeitada e dispensem da necessidade da instauração de um contencioso para a instituição do procedimento, é preciso que as regras procedimentais da JUR também sejam suficientes para resolver eventuais conflitos que surjam entre as partes quando da instauração da arbitragem.

Conforme visto no Capítulo 4, a JUR prevê um procedimento aleatório de indicação dos árbitros em determinado procedimento de forma que para a determinação de um tribunal arbitral seria necessário às partes apenas apontar

\footnotetext{
${ }^{53}$ PINTO, José Emílio Nunes. A cláusula compromissória à luz do código civil. In Doutrinas Essenciais de Arbitragem e Mediação, 2014. pp. 221-238.

${ }^{54}$ Ibid. pp. 221-238.
} 
o Arbitration Hub que administrará a disputa e se o procedimento será resolvido por árbitro único ou por um tribunal arbitral composto por três árbitros 55 .

Como se viu, a JUR oferece um ambiente que consolida os Arbitration Hubs e tem como premissa dar a eles o máximo de liberdade possível para que possam estabelecer seus próprios regulamentos com suas próprias regras. Nesse sentido, o JUR não prevê qualquer solução para a ausência de indicação pelas partes do número de árbitros que resolverão aquele conflito. Assim, ficaria a cargo de cada Arbitration Hub estabelecer suas respectivas regras e soluções para tal situação. $\mathrm{Na}$ ausência de estipulação pelo Arbitration Hub, contudo, não chegando as partes a um consenso quanto ao número de árbitros, não haverá outro caminho senão a adoção do procedimento contencioso previsto no art. $7^{\circ}$ da Lei de Arbitragem.

O mesmo se daria na ausência de estipulação ou consenso entre as partes acerca da escolha do Arbitration Hub.

Por fim, como se verá melhor no capítulo sobre procedimento, a Lei de Arbitragem estabeleceu no art. 21 que, não havendo estipulação acerca do procedimento pelas partes, caberá ao árbitro ou ao tribunal arbitral disciplinálo. Assim é que, instituído o tribunal arbitral ou determinado o árbitro, as demais lacunas procedimentais deixadas pelas partes ou pelos regulamentos dos Arbitration Hubs poderão ser solucionadas pelos árbitros.

\subsection{A Escolha dos Árbitros}

A Lei de Arbitragem em seu art. 13 determina que as partes deverão indicar os árbitros - ou árbitro - que vão compor o tribunal arbitral, podendo

\footnotetext{
${ }^{55}$ A JUR determina apenas que os procedimentos deverão ser resolvidos por árbitro único ou por um tribunal composto por três árbitros.
} 
ainda estabelecer o processo de escolha do árbitro ou apenas indicar as regras de algum órgão arbitral como aquelas que deverão ser observadas.

Antes de mais nada, deve-se atentar ao fato de que, apesar de muitos defenderem que a possibilidade de as partes indicarem aqueles que irão decidir o conflito é dos maiores benefícios trazidos pela arbitragem ${ }^{56}$, não há óbice a que a indicação acima referida não seja feita diretamente pelas partes mas sim por um terceiro predeterminado para tanto, devendo haver nesse caso previsão na convenção de arbitragem ou, no caso de arbitragens institucionais, previsão no regulamento do órgão institucional ${ }^{57}$ :

Em primeiro lugar, as partes apontam os árbitros: qualquer que seja o método adotado para a indicação, não há dúvida quanto à intenção das partes de outorgar a uma pessoa o poder de resolver a sua disputa. É irrelevante que em alguns casos um terceiro predeterminado ou uma instituição seja no final das contas responsável pela seleção dos árbitros ou confirmação da indicação. Eles o fazem em nome das partes, que já acordaram de antemão que os árbitros podem ser apontados indiretamente ${ }^{58}$.

Ainda sobre essa possibilidade, veja-se o precedente da CCI:

The parties accepted, in the arbitration clause, an arbitration procedure subject to the Rules of Arbitration of the ICC. The Claimant submitted its Request for Arbitration dated 12 May 1980, in accordance with the said Rules and, also in conformity with them, the Court of Arbitration appointed the arbitrators. That the Court was not able to appoint an arbitrator proposed by the respondents following the example of the claimant which had made a proposal which was accepted - is the inevitable result of their "consority" on the one hand and on the other hand the lack of agreement on the nomination of a joint arbitrator.

The appointment of the present Tribunal by the Court of Arbitration of the ICC was in conformity with the Rules of the Court of Arbitration ${ }^{59}$.

\footnotetext{
56“ O árbitro é livremente escolhido pelas partes. A possibilidade de as partes poderem escolher a pessoa ou pessoas que resolverão o conflito é, em nossa opinião um dos maiores beneficios que traz a arbitragem" (PUCCI, Adriana Noemi. Juiz \& Árbitro. In. Aspectos Atuais da Arbitragem. Rio de Janeiro: Forense, 2001).

57 "Se não há previsão na cláusula compromissória nem no regulamento do centro de arbitragem, a parte não pode ser alijada da escolha do árbitro. Caso isso ocorra, dá margem ao debate sobre a violação do principio da igualdade". (NANNI, Giovani Ettore. Notas sobre os negócios jurídicos da arbitragem e a liberdade de escolha do árbitro à luz da autonomia privada. In Revista de Arbitragem e Mediação. 2016. pp. 263-284.)

${ }^{58}$ Ibid. pp. 263-284.

${ }^{59}$ Caso CCI no 3.879 , sentença 5 de março de 1984.
} 
Conforme explica Giovanni Etore Nanni, as partes ao abordarem determinada pessoa para atuar como potencial árbitro no procedimento arbitral lhe fazem uma oferta, o árbitro indicado poderá então aceitar ou rejeitar essa proposta, dando ou não início ao contrato de árbitro a depender de sua aceitação ${ }^{60}$. A escolha do árbitro pelas partes é apenas uma etapa na formação do negócio jurídico arbitral que, por sua vez, perpassa o instituto da liberdade de escolha ${ }^{61}$.

A liberdade de escolha "nada mais representa do que a possibilidade de definir a contraparte", ou seja, ao celebrar o negócio jurídico arbitral, as partes têm liberdade para definir com quem vão contratar ${ }^{62}$. Esta, contudo, é sujeita a alguns limites.

Às partes é facultado escolher qualquer pessoa que tenha capacidade para atuar como árbitro, isto é, nos termos da lei, qualquer pessoa capaz, que tenha a confiança das partes e que não esteja sujeita a qualquer dos casos de suspeição ou impedimento dos juízes.

A capacidade, conforme explica Pedro Batista Martins:

"é atinente, particularmente, ao ramo do direito civil e é dele que o intérprete extrairá a validade da nomeação do árbitro. Incapaz a pessoa do árbitro, transgredida estará norma de ordem pública arbitral" subjetivo mas que diz respeito às partes que conformam a relação processual (...) traduz-se na ausência de impedimentos de fato e de direito necessária ao exercício do múnus publicum. Competência, independência e imparcialidade são axiomas que exprimem e em que se funda a confiança" ${ }^{\text {. }}$.

Em linha com o acima apontado, a Lei de Arbitragem determina que o árbitro proceda com imparcialidade, independência, competência,

\footnotetext{
${ }^{60}$ NANNI, Giovani Ettore. Op. Cit. pp. 263-284.

${ }^{61}$ Ibid. pp. 263-284.

62 "Depois de livremente se decidir a contratar, cada um de nós tem ainda a faculdade de eleger livremente a pessoa com quem pretende fechar o contrato - caso ela também esteja disposta a negociar conosco" (GOMES, Orlando. Contratos. Rio de Janeiro: Forense, 2001. pp. 22-25).

${ }^{63}$ MARTINS, Pedro Batista. Apontamentos sobre a Lei de Arbitragem. Rio de Janeiro: Forense, 2008. p. 186

${ }^{64}$ Ibid. p. 186
} 
diligência e discrição ${ }^{65}$, valores estes que marcam a conduta dos árbitros e não podem ser afastados ${ }^{66}$. Nesse sentido, a liberdade de escolha do árbitro é tolhida em função de restrições legais e convencionais:

O árbitro precisa ser capaz e desfrutar da confiança das partes (art. 13, caput, da Lei 9.307/1996). Portanto, não pode ser qualquer um. É necessária uma criteriosa seleção, que, repita-se, é uma detalhada definição acerca de quem contratar.

Em função das especialidades da avença, que atribui poder jurisdicional ao árbitro, a liberdade de escolha não é ilimitada, eis que a autonomia privada das partes é circunscrita. Há restrições, tanto legais como convencionais. Por exemplo, o indivíduo A não pode eleger como árbitro seu irmão $B$, na disputa que trava com $C$, com o qual não mantém nenhum vínculo de parentesco.

É um óbice legal, que restringe a autonomia privada, afetando o poder de selecionar um árbitro, a fim de assegurar a imparcialidade e a independência do julgador ${ }^{67}$.

A imparcialidade, conforme explica o já citado Pedro Batista Martins, diz respeito a uma atuação ética sob o ângulo da aplicação do direito manifestada dentro dos limites da atuação processual do árbitro ${ }^{68}$. A independência, por sua vez, diz respeito à falta de vinculação pessoal ou profissional a uma das partes da arbitragem ou ao seu objeto. A avaliação da independência deve, conforme assevera o autor, ser realizada a partir da lógica, da ponderação e do bom senso:

\begin{abstract}
Por certo, não há de ser qualquer vínculo ou ligação, profissional com uma das partes que irá macular a independência do árbitro. Mesmo se, diante dos olhos da parte, a pessoa indicada transparecer certo grau de dependência, sua impugnação poderá não lograr êxito na aferição que venha a ser feita pela secretaria do órgão arbitral em que se processo a arbitragem ${ }^{69}$.
\end{abstract}

É nesse contexto que surge o dever legal daqueles que foram indicados a atuar como árbitros de, antes da aceitação da função, revelar qualquer fato

\footnotetext{
${ }^{65}$ NANNI, Giovani Ettore. Op. Cit. pp. 263-284.

${ }^{66}$ MARTINS, Pedro Batista. Op Cit. p. 188

67 "No que tange ao negócio jurídico arbitral, a pessoa tem a faculdade de escolher com quem contratar, em outras palavras, quem indicar como árbitro. Mas, no seu exercício, conta com uma limitação legal insuperável, que é o imperativo de o árbitro ser imparcial e independente, que constitui inolvidável garantia do devido processo legal, em atenção à ordem pública". (NANNI, Giovani Ettore. Op Cit. pp. 263-284.)

${ }^{68}$ MARTINS, Pedro Batista. Op. Cit. p. 188

${ }^{69}$ Ibid. p. 188
} 
ou circunstância que denote dúvida justificada quando à sua imparcialidade. Este dever perdura durante toda a duração do procedimento arbitral.

Além do acima exposto, a Lei de Arbitragem exige ainda que o árbitro seja competente. A Lei busca nesse ponto apresentar um contraposto ao juiz togado, na medida em que espera que o árbitro indicado seja um especialista com razoável experiência na matéria capaz de proferir uma decisão técnica. Veja-se a seguir as lições de Carlos Alberto Carmona acerca do tema:

Quer a lei que o árbitro seja competente, isto é, que tenha conhecimento, aptidão e capacidade que o habilitem a dirimir a controvérsia que lhe será submetida. Espera-se que o julgador escolhido pelas partes seja um especialista no assunto e que tenha razoável experiência na matéria (...) quer-se do árbitro, não se pode esquecer, decisão técnica, especializada, melhor do que aquela que seria de esperar de um juiz estatal ${ }^{70}$ !

Leciona ainda Carlos Alberto Carmona que quando as partes delegam a indicação do árbitro para um órgão institucional, tal como é feito no sistema JUR, estas geralmente indicam determinados requisitos que devem ser preenchidos para que possa haver a indicação de determinado árbitro:

Não raro, estabelecem as partes, quando delegam a indicação de árbitros a órgãos institucionais, que o julgador deverá ter um mínimo de tantos anos de experiência em tal ou qual atividade, ou que deverá ter participado de uma grande empresa de determinado ramo pelo menos durante tantos anos ${ }^{71}$.

O sistema vislumbrado pela JUR segue o procedimento inverso ao mencionado acima pelo autor. Na escolha de árbitros do JUR, os Hub Admins estabelecem previamente os critérios que devem ser atingidos para que determinada pessoa possa integrar seu corpo de árbitros que será depois usado como base para um sorteio aleatório. Os critérios adotados por cada Arbitration $H u b$ ficam à disposição das partes a todo o tempo. Assim, quando da escolha deste ou daquele Arbitration Hub as partes devem fazer uma análise detida sobre os critérios escolhidos pelos Hub Admins de forma a

\footnotetext{
${ }^{70}$ CARMONA, Carlos Alberto. Op Cit. pp. 209-210.

${ }^{71}$ CARMONA, Carlos Alberto. Op Cit. p. 209.
} 
submeter conflitos que sejam compatíveis com as qualificações daquele determinado corpo de árbitros. Ao escolher um Arbitration Hub, contudo, as partes concordam com aqueles critérios e estão tacitamente aceitando-os como suficientes para a aferição da competência daqueles que venham a integrar o tribunal arbitral responsável pela resolução do seu conflito.

A escolha do árbitro não é, portanto, definitiva. Sendo certo que a Lei prevê o direito das partes de apresentar impugnações com fundamento na falta de observância dos ditames acima descritos.

Conclui-se do acima disposto que a análise dos elementos de confiança das partes nos árbitros é sujeita a certo grau de subjetividade. O JUR, como já se viu acima, prevê com relação à escolha dos árbitros um mecanismo de seleção de árbitros absolutamente aleatório o que, na visão da JUR seria suficiente para garantir a imparcialidade e independência dos árbitros. A referida indicação indireta pode trazer benefícios ao procedimento na medida em que elimina quaisquer dúvidas acerca da vinculação dos árbitros às partes na medida em que terão sido indicados aleatoriamente, sem qualquer abordagem pelas partes ${ }^{72}$.

\footnotetext{
72 "Não se pode ignorar, entretanto, que, ao indicar um árbitro, a parte cria uma certa expectativa sobre ele, a qual certamente não existe quanto ao árbitro-presidente. Na fase de indicação dos árbitros, cada parte elou seu advogado costumam empreender um minucioso e detalhado trabalho em busca do 'árbitro ideal' para aquele caso especifico, o que é plenamente justificável. Entretanto, a parte jamais deve esperar, em função isso, que o árbitro vá se comportar como um representante seu no painel arbitral: alguém disposto a fazer o que for necessário para defender os interesses da parte que o indicou. O árbitro nomeado deve julgar o caso com base na devida apreciação do mérito da causa e proferir seu voto de acordo com seu sincero e real entendimento - tal qual o árbitro presidente -, sendo-lhe indiferente se ele irá contribuir para que a parte que o indicou ou a outra parte vença a controvérsia. Se a parte pode ter alguma expectativa sobre o árbitro que nomeou, esta deve se limitar ao que foi mencionada anteriormente; que ele irá ouvir seus argumentos com atenção, examinar os documentos adequadamente, exercer o papel de tradutor perante os demais árbitros etc". (VERÇOSA, Fabiane. A liberdade das partes na escolha e indicação de árbitros em arbitragens internacionais: Limites e possibilidades. In Revista de Arbitragem e Mediação. São Paulo: Editora Revista dos Tribunais, 2004. p. 341).

No mesmo sentido: "Embora não se consiga preservar, como visto, a imparcialidade como valor absoluto no sistema de indicação de árbitros "de parte", é verdadeiro que algumas cautelas devem ser tomadas para evitar comprometimento da capacidade de julgar com isenção. Por isso, diversas entidades arbitrais criam códigos de abordagem aceitável dos futuros nomeados até os casos de afastamento do árbitro que demonstrar conduta comprometida ou tendenciosa. Nesta esteira, importa lembrar que a parte que pretende envolver-se num julgamento arbitral pode perscrutar o
} 
A despeito dos benefícios que esse modelo de indicação de árbitro possa trazer, tendo em vista a subjetividade da matéria bem como sua natureza volátil, isto é, podem vir a surgir ou bem as partes podem vir a tomar conhecimento de determinados fatos que abalem a confiança delas nos árbitros ou que ponham em dúvida a imparcialidade e independência deles a todo momento durante o procedimento, não parece ser possível estabelecer um procedimento que seja imune a tais subjetividades. Assim, não há uma indicação, por mais aleatória que seja, que possa ser imune, a priori, a eventuais impugnações.

Não há, contudo, no White Paper da JUR qualquer menção à possibilidade de apresentação de impugnações, nem tampouco previsão de um procedimento para tanto. Ficaria a critério, portanto, dos Hub Admins, regular a forma com que essas impugnações poderiam ser apresentadas. $\mathrm{Na}$ ausência de previsão pelos $H u b$ Admins contudo, tendo em vista a previsão do art. 15 da Lei de Arbitragem ${ }^{73}$, não poderiam os árbitros ou o próprio Hub Admin se recusar a conhecer eventuais impugnações apresentadas pelas partes, sob pena de nulidade do procedimento.

\subsection{Procedimento}

A lei de arbitragem é clara em seu art. 19 quanto ao momento da instituição da arbitragem, isto é, opera-se com a aceitação da nomeação pelo árbitro, no caso de árbitro único, ou por todos se forem vários. Nesse sentido,

especialista que quer indicar para compor o painel; tal sondagem prévia, entretanto, deve necessariamente limitar-se a impedimentos profissionais, pois, se a consulta ao futuro árbitro exceder estes estreitos limites, haverá base fundada para alegação de suspeição". (CARMONA, Carlos Alberto. Op. Cit. p. 209.)

73 “Art. 15. A parte interessada em argüir a recusa do árbitro apresentará, nos termos do art. 20, a respectiva exceção, diretamente ao árbitro ou ao presidente do tribunal arbitral, deduzindo suas razões e apresentando as provas pertinentes.

Parágrafo único. Acolhida a exceção, será afastado o árbitro suspeito ou impedido, que será substituído, na forma do art. 16 desta Lei”. (Lei de Arbitragem) 
"somente com a aceitação pelo último árbitro se implementa a condição de existência e validade do tribunal arbitral"74.

Antes de preenchida essa condição, não há que se falar em tribunal arbitral, nem tampouco existe ainda a jurisdição arbitral para fins de direito. Por esse motivo, qualquer tutela que venha a ser requerida pelas partes antes da instituição da arbitragem, que - repita-se - ocorre com a aceitação de todos os árbitros que comporão o tribunal arbitral, deve ser realizada perante o poder judiciário ${ }^{75}$.

Não há na Lei de Arbitragem, contudo, qualquer prescrição quanto à forma com que essa aceitação pelos árbitros se opera:

Registre-se que a lei não prescreveu nenhum tipo de formalidade que devesse ser observada pelos árbitros ou buscada pelas partes, de modo a comprovar a aceitação.

Com efeito, resta sem amarras a formalização desse ato, sendo passível de comprovação por todos os meios lícitos de prova. Basta a ocorrência de qualquer modalidade de ato capaz, por si só, de constituir os direitos pertinentes.

A aceitação não há de ser expressa, necessariamente; pode, pois, gerar efeitos jurídicos se implementada tacitamente. O que a lei exige é a ocorrência de alguma modalidade de ato jurídico, por parte dos árbitros, suficiente a confirmar a aceitação da obrigação para a qual foram nomeados ${ }^{76}$.

Nesse sentido, a aceitação da arbitragem pelos árbitros pode ser comprovada "por todo e qualquer meio"77.

A JUR não prevê qualquer tipo de procedimento ou forma para este aceite. Conforme já explorado no capítulo sobre o funcionamento do JUR, este, com o intuito de dar liberdade às Arbitration Hubs e de estimular a competitividade entre os regulamentos, deixa uma série de questões ao critério dos Hub Admins. Nesse sentido nada impede e é inclusive

\footnotetext{
${ }^{74}$ MARTINS, Pedro Batista. Op Cit. p. 226

${ }^{75}$ MARTINS, Pedro Batista. Op Cit. p. 226

${ }^{76}$ MARTINS, Pedro Batista. Op. Cit. pp. 226-227

${ }^{77}$ MARTINS, Pedro Batista. Op Cit. p. 227.
} 
recomendável que cada $H u b A d m i n$ estabeleça o procedimento para aceite dos árbitros nos Arbitration Hubs. No silencio dos regulamentos dos Arbitration Hubs contudo, e à vista da inexistência de uma prescrição de forma para o aceite dos árbitros, a prática de qualquer ato processual pelos árbitros será reputada como aceite, uma vez que este pode ser comprovado de qualquer forma e essa atuação é incompatível com a rejeição da nomeação.

Quanto ao procedimento em si que será adotado na arbitragem, a Lei de Arbitragem chancela em seu art. 21 o princípio mais caro ao instituto da arbitragem que é, como já visto neste trabalho, a liberdade das partes de convencionar da forma que melhor lhes convier, podendo elas adotar as regras de um órgão arbitral já existente, estabelecerem elas mesmas as regras do procedimento ou até mesmo deixar ao livre arbítrio dos árbitros a definição das normas procedimentais.

Assim, à luz do princípio da autonomia da vontade que norteia a arbitragem, dá -se às partes o poder de definir o procedimento que será aplicável, cabendo aos árbitros a definição das regras procedimentais, na ausência de manifestação delas.

A nova lei incorpora ao direito brasileiro de arbitragem o princípio da autonomia do procedimento arbitral. As partes podem, assim, determinar as normas aplicáveis ao procedimento da arbitragem, referindo-se a um regulamento arbitral, ou ainda conferir aos árbitros o poder de regulamentar este procedimento (art. 21).

Ao contrário da legislação argentina - que, na ausência de manifestação das partes quanto às normas aplicáveis ao procedimento arbitral, aplica as regras previstas no Código de Processo Civil -, o novo direito brasileiro da arbitragem reserva aos árbitros o poder de determinar as normas que serão aplicadas ao processo arbitral. $O$ sistema brasileiro se integra ao movimento legislativo que atribui aos árbitros a autonomia de decidir sobre o procedimento arbitral ${ }^{78}$.

Nesse sentido, a arbitragem é dotada de grande flexibilidade que permite que as partes 'criem o procedimento arbitral 'sob medida' para as

\footnotetext{
${ }^{78}$ LEE, João Bosco. A Especificidade da Arbitragem Comercial Internacional. In CASELLA, Paulo Borba Casella, Arbitragem - lei brasileira e praxe internacional. São Paulo: LTr, 1999. p. 183.
} 
necessidades da disputa que se busca resolver (na expressão inglesa comumente utilizada, um procedimento 'tailormade')"79. Tal flexibilização, contudo, muitas vezes é pouco aproveitada pelas partes que ao invés de adequarem o procedimento às suas necessidades, optam por formulas préprontas que são muitas vezes insuficientes para regular as particularidades do caso. Nesse sentido, veja-se a conclusão de um estudo da Queen Mary University of London - School of International Arbitration:

One concern that was expressed by experienced practitioners during interviews was that arbitral procedure is gradually too rigid and formulaic. It was said that when determining the procedural framework at the outset of proceedings, arbitrators should take parties' expectations more into consideration and tailor the procedure to the particularities of each case, rather than simply following general procedural templates ${ }^{80}$.

No mesmo sentido, veja-se o relatório CCI sobre como controlar o tempo e os custos de uma arbitragem:

One of the salient characteristics of arbitration as a dispute resolution mechanism is that the rules of arbitration themselves present a framework for arbitral proceedings but rarely set out detailed procedures for the conduct of the arbitration. For example, rules of arbitration do not generally specify whether there should be one, two or more exchanges of briefs. They do not contain any detailed provisions concerning document production. They do not specify how hearings should be conducted and how witnesses, if any, should be heard.

This important characteristic entails that the specific procedures can be tailormade as appropriate for each dispute and adapted to the legal cultures of the parties and the arbitrators. In order to establish the appropriate procedures for a given arbitration, it is useful and efficient for the parties and the tribunal to make conscious decisions as early as possible on the procedures best suited to the dispute at hand. In making those decisions, it is possible to shape the arbitral proceedings so that the duration and cost of the arbitration are commensurate with what is at stake in the case and appropriate in light of the claims and issues presented ${ }^{81}$.

\footnotetext{
79 FALEK, Diego. ALVES, Rafael. Concordar em discordar: por quê, o quê e como negociar o procedimento arbitral. In Revista de Direito Empresarial, 2014. p. 249.

${ }^{80}$ Queen Mary. 2012 International Arbitration Survey: Current and Preferred Practices in the Arbitral Process. Disponível em http://www.arbitration.qmul.ac.uk/media/arbitration/docs/2012 International_Arbitration_Survey. pdf > Acesso em 18 Nov. 2019.

${ }^{81}$ CCI. ICC Commission Report. Controlling Time and Costs in Arbitration. Disponível em $<$ https://www.iccwbo.be/wp-content/uploads/2012/03/20151101-Controlling-Time-and-CostsReport.pdf $>$ Acesso 18 Nov. 2019.
} 
Parece ser exatamente esse nicho que as Online Dispute Resolutions buscam conquistar. O ODR é pensado para aqueles que, a partir de uma compreensão de que nem todas as arbitragens devem seguir a mesma estrutura de procedimento, estão dispostos a abrir mão de certas formulas tradicionais de procedimento para com isso alcançar um procedimento mais célere, simples e barato que se adéque às suas necessidades tendo em vista as particularidades da relação entre as partes.

Carlos Alberto Carmona chama atenção ao fato de que, por falta de ânimo no momento da contratação, é incomum as partes estabelecerem normas procedimentais mais pormenorizadas antes da efetiva instauração do conflito. Mais comum é que estas estabeleçam as regras do procedimento depois do surgimento do conflito, por meio do compromisso arbitral, ainda que este não seja, a rigor, necessário à vista de uma cláusula compromissória cheia.

O primeiro critério certamente não é o mais usual: raramente as partes na cláusula compromissória (convenção de arbitragem que será responsável pela introdução da maior parte das arbitragens), preocupam-se em estabelecer um procedimento que poderá ser utilizado para a solução de suas futuras controvérsias. A cláusula compromissória, tem sido notado, é naturalmente uma das últimas (senão a última) disposições contratuais a ser negociada, e os contratantes estão já razoavelmente esgotados, sendo difícil imaginar que, no fechamento do contrato, estarão as partes animadas a criar um procedimento a ser aplicado para a eventualidade de surgir um litígio (eventual e incerto) entre elas, versando aquela relação jurídica que acabam de emoldurar! Já na eventualidade de instituir-se a arbitragem através de compromisso arbitral, onde a negociação das partes concentra-se exatamente na forma de resolver uma controvérsia já surgida, a criação de um procedimento especial a ser empregado pelo árbitro pode ser uma opção mais interessante: sabendo-se exatamente qual o objeto do processo arbitral e quem serão os árbitros, podem as partes estabelecer confortavelmente um procedimento especial para resolver seu litígio que seja adequado aos problemas que o árbitro enfrentará, levando em consideração a necessidade de deslocamentos, a dificuldade técnica e jurídica do tema a ser tratado, a necessidade ou não de produção de provas constituendas, o tempo em que desejam seja proferida a decisão entre tantos fatores relevantes (... ${ }^{82}$.

O relatório da CCI sobre como reduzir custos e o tempo de um procedimento arbitral também aponta para a mesma dificuldade ao analisar a

\footnotetext{
${ }^{82}$ CARMONA, Carlos Alberto. Op. Cit. p. 249
} 
previsão de adoção de um procedimento expedito, o fast-track procedure. Ao redigir as cláusulas compromissórias as partes muitas vezes ainda não têm condições de prever se o conflito que eventualmente surja entre elas será adequado a uma análise expedita:

Consideration may be given to setting out fast-track procedures in the arbitration clause. Indeed, Article 38(1) of the Rules enables the parties to shorten time limits provided for in the Rules, while Article 38(2) enables the Court to extend those shortened time limits when necessary. Fast-track procedures are designed to enable an arbitration to proceed quickly, given the specific nature of the contract and the disputes that are likely to arise. However, experience shows that in practice it is difficult at the time of drafting the clause to predict with a reasonable degree of certainty the nature of disputes and the procedures that will be suitable for those disputes. Also, disagreements can arise later over the interpretation or application of fast-track clauses. Careful thought should therefore be given before such provisions are included in an arbitration agreement. Once a dispute has arisen, the parties could at that time agree upon a fast-track procedure, if appropriate ${ }^{83}$.

É comum, contudo, que as partes ao instalarem uma arbitragem celebrem um termo de compromisso (esse documento pode ter outros nomes, como por exemplo, a ata de missão ou o termo de arbitragem) ainda que este não seja obrigatório. Isso porque, surge nesse momento a oportunidade de regularem aspectos procedimentais que tenham ficado de fora no momento da celebração da cláusula compromissória, aprimorando o uso da arbitragem à vista do conflito ${ }^{84}$.

Como já se viu no capítulo acerca do funcionamento do JUR, este prevê três tipos de procedimento que têm graus de complexidade que variam conforme os valores envolvidos na disputa e da matéria objeto de controvérsia.

Nesse sentido, o momento mais apropriado para o detalhamento de um procedimento online e da escolha por exemplo do procedimento que será adotado pelas partes - se a arbitragem documental, a arbitragem rápida ou a

\footnotetext{
${ }^{83}$ CCI. ICC Commission Report. Controlling Time and Costs in Arbitration. Disponível em $<$ https://www.iccwbo.be/wp-content/uploads/2012/03/20151101-Controlling-Time-and-CostsReport.pdf> Acesso 18 Nov. 2019.

${ }^{84}$ FALEK, Diego. ALVES, Rafael. Op. Cit. p. 249.
} 
arbitragem comum ${ }^{85}$-parece ser depois do surgimento do conflito, quando seu nível de complexidade e os valores envolvidos já estejam mais palpáveis para as partes ${ }^{86}$. Sobre esse ponto, deve-se atentar a um dever das partes de se manterem aberta à negociação, mesmo após a instauração de um conflito:

Uma vez estabelecido o comprometimento das partes com a escolha da arbitragem, fica claro, na prática, que elas devem estar abertas para, na medida do possivel, negociar as regras procedimentais a fim de obter soluções de benefício mútuo e, assim, estabelecer um consenso mínimo depois do qual a adversariedade entrará em cena. Essa é a importância do exercício da consensualidade, que não se esgota na escolha da arbitragem e devem prosseguir também durante a sua operacionalização ${ }^{87}$.

$\mathrm{Na}$ ausência de consenso entre as partes acerca do tipo de procedimento que será adotado, caberá, nos termos da lei, ao tribunal arbitral decidir qual dos três procedimentos melhor se adequa ao caso, sendo certo que a própria JUR prevê a competência dos árbitros para tanto.

Como já visto, a jurisdição do Tribunal Arbitral surge da convenção $\operatorname{arbitral}^{88}$, tendo os árbitros poderes para decidir o procedimento no silencio das partes. O limite da atuação dos árbitros, ainda que não sujeita em regra às normas de processo civil brasileiras ${ }^{89}$, é o respeito aos princípios fundamentais do processo tais como o contraditório, a igualdade das partes, a imparcialidade dos árbitros e o seu livre convencimento, conforme positivado no art. $21 \S 2^{\circ}$ da Lei de Arbitragem.

O Tribunal Arbitral, destarte, conduzirá o processo a seu cargo segundo regras de procedimento que não são exatamente as mesmas aplicáveis aos juizos ordinários. Deve, no entanto, respeitar os principios fundamentais do processo como, entre outros, os pertinentes à limitação da sentença ao pedido das partes,

\footnotetext{
${ }^{85}$ Vide Capítulo 4.2.2.

86"If the parties agree to submit a dispute to ICC arbitration after the dispute has arisen, they can consider specifying in some detail the procedure for the arbitration, taking into account the nature of the dispute in question. This procedure may include some of the suggestions set out below to control time and costs". (CCI. ICC Commission Report. Controlling Time and Costs in Arbitration. Disponível em $<$ https://www.iccwbo.be/wp-content/uploads/2012/03/20151101-Controlling-Timeand-Costs-Report.pdf $>$ Acesso 18 Nov. 2019.)

${ }^{87}$ FALEK, Diego. ALVES, Rafael. Op. Cit. P. 249.

${ }^{88}$ MARTINS, Pedro Batista. Op. Cit. p. 232

${ }^{89}$ É facultado às partes estabelecer a aplicação das regras processuais civis brasileiras, caso queiram.
} 
ao debate dialético das pretensões contrapostas, à investigação da verdade real, à motivação do julgado, à formação da coisa julgada etc. (...)

A garantia do devido processo legal com os consectários do contraditório e ampla defesa são, modernamente, direitos assegurados no plano constitucional, o mesmo ocorrendo com a exigência de motivação de todas as decisões judiciais (CF, art. $5^{\circ}$, LIV e LV, e art. 93, IX). Por isso, qualquer que seja o procedimento a prevalecer no juizo arbitral, esses preceitos fundamentais nunca poderão ser descurados pelos árbitros, sob pena de nulidade. A matéria é de ordem pública e não se sujeita à disponibilidade negocial na convenção de arbitragem ${ }^{90}$.

Isso porque a arbitragem é uma técnica compositiva de natureza híbrida uma vez que ao mesmo tempo que possui natureza contratual sendo, portanto, fundada na autonomia das partes, é atividade jurisdicional sujeita às garantias do devido processo legal que limitam a autonomia das partes e a atuação dos árbitros e órgãos arbitrais ${ }^{91}$.

Mas o que então representa uma afronta às garantias processuais?

Como já se viu acima no Capítulo 4, uma das formas de que a JUR se utiliza para trazer celeridade ao processo e reduzir custos é a limitação tanto das manifestações das partes quando até mesmo das provas que serão produzidas no procedimento. Deve-se então analisar em que medida tais limitações são compatíveis com o devido processo legal.

Na arbitragem, à luz do art. 21 da Lei de Arbitragem, a regra é que as partes possam desenhar o procedimento "como bem entenderem", devendo aproveitar essa liberdade que lhes é conferida em sua "máxima amplitude"92.

\footnotetext{
${ }^{90}$ JUNIOR, Humberto Theodoro. Arbitragem e Terceiros - Litisconsórcio fora do pacto arbitral outras intervenções de terceiros. In Reflexões sobre arbitragem in memoriam do Desembargador Cláudio Vianna de Lima. São Paulo: LTr, 2002. pp. 246-248.

${ }^{91}$ FALEK, Diego. ALVES, Rafael. Op. Cit. p. 249. No mesmo sentido: "Defluem das considerações acima expendidas ser mais acertado definir a natureza jurídica da arbitragem como híbrida, sendo na sua primeira fase contratual e na segunda jurisdicional, o que nos autoriza invocar os mesmos princípios jurídicos e corolários informadores do processo judicial, a fim de que se garanta a tutela jurídica efetiva". (LEMES, Selma Maria Ferreira. Arbitragem. Principios Jurídicos Fundamentais. Direito Brasileiro e Comparado. In Doutrinas Essenciais Arbitragem e Mediação, 2014. pp. 215248).

${ }^{92}$ FALEK, Diego. ALVES, Rafael. Op. Cot. p. 249.
} 
Essa é, inclusive, a recomendação da CCI por exemplo em seu relatório sobre como reduzir custos e o tempo de uma arbitragem. Nele, a CCI sugere uma série de flexibilizações procedimentais, bem como propõe diversas reflexões que as partes devem observar ao desenhar seu procedimento.

Vejam-se alguns exemplos de flexibilizações propostas pela CCI no referido relatório: (i) as partes devem analisar a necessidade de se realizar uma audiência para que os árbitros possam decidir sobre a causa ou se aquela disputa pode ser decidida apenas com base na análise de documentos ${ }^{93}$;e (ii) as partes devem evitar a repetição em suas manifestações, expondo de partida todos os seus argumentos e nesse sentido devem analisar a conveniência de limitar tanto o número de manifestações como também o tamanho delas ${ }^{94}$.

Nesse contexto, sendo desejável às partes à luz dos contornos específicos da relação e do conflito entre elas simplificar procedimentos, é permitido a elas dispor sobre a produção de provas, tomada de depoimentos, número de testemunhas e até mesmo sobre a realização de uma audiência:

Se não for possivel ou desejável (por razões estratégicas) restringir o objeto da arbitragem, as partes podem, pelo menos, acordar ou detalhar como a prova deverá ser produzida, novamente com o intuito de se evitar custos e atrasos desnecessários. Por exemplo, perícias técnicas podem ser dispensadas se as partes conseguirem chegar a um acordo sobre o ponto controvertido e perceberem que, na verdade, ele depende de uma decisão jurídica e não de um parecer técnico. Além disso, também é possivel chegar a um consenso quanto ao número de testemunhas ou ao tempo elou forma de sua inquirição, tudo a contribuir para um

\footnotetext{
93 "Consider whether or not it is necessary for there to be a hearing in order for the arbitral tribunal to decide the case. If it is possible for the arbitral tribunal to decide the case on documents alone, this will significantly reduce costs and time". (CCI. ICC Commission Report. Controlling Time and Costs in Arbitration. Disponível em $<\underline{\text { https://www.iccwbo.be/wp- }}$ content/uploads/2012/03/20151101-Controlling-Time-and-Costs-Report.pdf $>$ Acesso 18 Nov. 2019.)

94 "Avoid unnecessary repetition of arguments. Once a party has set out its position in full, it should not be necessary to repeat the arguments at later stages (e.g. in pre-hearing memorials, oral submissions or post-hearing memorials), and the arbitral tribunal may direct that there be no such repetition. (...)

Consider agreeing on limiting the length of specific submissions. This can help focus attention on the key issues to be addressed and is likely to save time and cost. (...)

Consider limiting the number of rounds of submissions. This may help to avoid repetition and encourage the parties to present all key issues in their first submissions". (Ibid.)
} 
desfecho mais rápido e eficiente do caso, sem prejuizo da formação do convencimento dos árbitros. Algumas vezes, até mesmo a audiência pode ser dispensada pelas partes, caso seja possivel decidir o caso somente com base na prova documental. Esse acordo das partes em dispensar a audiencia traria alivio significativo em relação aos custos e ao tempo da arbitragem ${ }^{95}$.

Assim, Mohamed S, Abdel Wahab, ao analisar o devido processo legal em arbitragens online, conclui que, à vista da natureza expedita do procedimento online, desde que as partes sejam tratadas igualmente e tenham oportunidades iguais para apresentar seus casos, o devido processo legal terá sido observado e o procedimento online será considerado válido:

The fundamental requirements of due process should be observed in e-arbitral proceedings. Due process is essential to ensure the fairness and impartiality of decisions. Parties should be allowed to present their case on equal grounds, present evidence and counterclaims, and be notified of other party's submissions. However, prolonged time limitations for submissions and strict formal procedural rules are not needed in ODR in general and online arbitration in particular, as they will hinder swift decisions. In so far as the parties are treated equally and given equal opportunities to present their cases, fairness is achieved and due process is observed. (...)

Accordingly, e-arbitral proceedings should not be rejected save in cases where online proceedings substantially and adversely affect due process requirements by impeding a party's effective communication and participation, which will result in the creation a form of 'virtual inequality"

Por fim, deve-se atentar também ao fato de que o devido processo

legal deve ser analisado à luz do caso concreto:

This being so, due process is a variable concept. The degree of due process required is dependent on the specificity of a particular case or category of cases, and the courts adjust their Standards of review accordingly. If time is of the essence, the arbitrators must act expeditiously and the parties must cooperate in achieving a prompt decision. For instance, if the parties offer relevant expert evidence, the arbitrators must accept it, but can restrict the time for expert proceedings to a very short time frame ${ }^{97}$.

\footnotetext{
${ }^{95}$ FALEK, Diego. ALVES, Rafael. Op. Cit. p. 249.

${ }^{96} \mathrm{WAHAB}$, Mohamed S. Abdel. ODR and e-arbitration - trends and challenges. In. KATSH, Ethan. WAHAB, Mohamed S. Abdel, RAINEY, Daniel. Op. Cit. p. 414

${ }^{97}$ KAUFMANN-KOHLER, Gabrielle. SCHULTZ, Thomas. Op. Cit. p. 33.
} 
À luz do acima exposto, os diferentes procedimentos simplificados previstos pela JUR a princípio não apresentam qualquer incompatibilidade com o instituto da arbitragem.

Por fim no que diz respeito ao procedimento, é preciso fazer uma pequena digressão a respeito de um fenômeno que vem se mostrando cada vez mais comum em procedimentos arbitrais, a paranoia do devido processo legal - conhecido na doutrina estrangeira como due process paranoia. Tal fenômeno consiste no proferimento de decisões excessivamente conservadoras, concedendo extensões de prazo, produção de provas e manifestações, impugnações, entre uma série de outras medidas, por medo de uma eventual anulação da sentença arbitral sob o fundamento de que umas das partes teve seu direito ao devido processo legal violado ${ }^{98}$. Em outra pesquisa sobre aprimoramento e inovação da arbitragem internacional realizada pela já citada Queen Mary University of London define o due process paranoia da seguinte forma:

"Due process paranoia" describes a reluctance by tribunals to act decisively in certain situations for fear of the arbitral award being challenged on the basis of a party not having had the chance to present its case fully. ${ }^{99}$.

O problema do due process paranoia, em linha com o que vem sendo apontado neste trabalho, é que ele contribui para procedimentos mais demorados e custosos que contrariam a própria lógica do instituto da arbitragem. Assim, quando o tribunal arbitral opta por decisões cautelosas

\footnotetext{
${ }^{98}$ Specifically, in recent years, a group of academics and practitioners in the field of international arbitration have increasingly raised concerns over an ongoing practice by arbitrators to render procedural decisions (e.g., extensions of time, postponement of hearings, discovery requests) out of fear that ruling otherwise would infringe on a party's due process rights. (BATES JR, Albert. TORRES-FLOWER, Zachary. Abuse of Due Process in International Arbitration: is due process paranoia irrational. In The American Journal of Construction Arbitration \& ADR, 2017. p. 246.)

${ }^{99}$ Queen Mary University of London. 2015 International Arbitration Survey: Improvements and Innovations in International Arbitration. Disponível em $<$ http://www.arbitration.qmul.ac.uk/media/arbitration/docs/2015_International_Arbitration_Survey .pdf> Acesso em 18 Nov. 2019.
} 
em prejuízo da economia e eficiência do procedimento arbitral, profere uma “"wasteful', 'uneconomical', decision"100.

Tal problema parece ser ainda mais patente em procedimentos como os previstos pela JUR em que há, de partida, uma limitação da produção de provas, manifestações etc... Assim, ainda que tal procedimento tenha sido acordado pelas partes, abre-se uma porta para que a parte perdedora maliciosamente argumente que não teve a oportunidade de devidamente apresentar seu caso como uma estratégia para reverter uma decisão que lhe seja desfavorável:

This inherent structural pressure has unfortunately given rise to a strategy by some parties to raise numerous procedural applications under the guise of due process to gain a perceived strategic advantage in the arbitration or at the set aside/enforcement stage. Importantly, these contrived strategies are not applications concerning legitimate and fundamental due process concerns, such as lack of note. Instead, the strategy generally involves repeated applications over mundane administrative or procedural disputes through which, whether expressly or implicitly, a party argues that the failure to grant the requested relief would result in a violations of that party's due process rights ${ }^{101}$.

É certo, contudo, que as alegações feitas com base nessa estratégia não configuram de forma alguma violação ao devido processo legal:

From afar, it is abundantly clear that the denial of such applications do not result in an even plausible violation of a party's due process rights ${ }^{102}$.

Nesse sentido, a pesquisa da Queen Mary University of London sobre aprimoramento e inovação da arbitragem internacional aponta que os entrevistados clamam por decisões mais incisivas pelos árbitros na condução do procedimento arbitral ${ }^{103}$. Cabe aos árbitros, portanto, zelar pela eficiência

\footnotetext{
${ }^{100}$ GERBAY, Remy. Due Process Paranoia. Disponível em $<$ http://arbitrationblog.kluwerarbitration.com/2016/06/06/due-process-paranoia/> Acesso em 18 Nov. 2019.

${ }^{101}$ BATES JR, Albert. TORRES-FLOWER, Zachary. Op. Cit. p. 251.

102 Ibid. p. 251.

103 “'(..) in practice, the risk of successful challenges to arbitral awards was 'insufficient to justify tribunals' overly cautious behavior; consequently, arbitrators should be willing to decisively manage proceedings" (Queen Mary University of London. 2015 International Arbitration Survey: Improvements and Innovations in International Arbitration. Disponível em
} 
do procedimento arbitral e atuar de forma a respeitar a intenção das partes naquele procedimento, sobretudo à vista da escolha de um procedimento simplificado.

\subsection{Sentença Arbitral}

A Lei de Arbitragem traz alguns requisitos relativos à sentença arbitral. O primeiro deles é que a sentença seja proferida em documento escrito (art. 24 da Lei de Arbitragem). Tal determinação, conforme explica Carlos Alberto Carmona, existe como uma forma de limitar a criatividade das partes na formação de um procedimento excessivamente expedito, impedindo a prolação de sentenças orais:

Embora possam as partes convencionar que o procedimento seja expedito e que a sentença seja proferida em periodo bastante exíguo, a Lei prevê alguns requisitos de validade do laudo, limitando a criatividade e imaginação dos contendentes.

Dessa sorte, será nula a sentença arbitral proferida oralmente, ainda que registrada em áudio ou vídeo.

A limitação quanto à forma, imposta pela Lei, é razoável na medida em que, sendo eventualmente necessário executar a sentença arbitral, não se poderia exigir que o juiz togado lidasse com títulos executivos nebulosos ou esdrúxulos, o que nenhum beneficio traria para a tutela de direitos e para a obtenção da certeza que se esperada de qualquer sentença, judicial ou arbitral ${ }^{104}$.

No mesmo sentido, Pedro Batista Martins explica que, ainda que deva o processo "perseguir, ao máximo, a oralidade (...) o ato jurisdicional que põe fim à controvérsia há de vir expresso em documento"105.

Tem-se assim que o espírito da determinação legal de que as sentenças sejam proferidas em documento escrito é o de coibir a entrega de decisões pela via oral. Não obstante ser essa a intenção da Lei, tem-se que os tempos modernos impõem uma dificuldade a esse requisito na medida em que é

$<\underline{\text { http://www.arbitration.qmul.ac.uk/media/arbitration/docs/2015 International_Arbitration_Survey }}$ .pdf> Acesso em 18 Nov. 2019.)

${ }^{104}$ CARMONA, Carlos Alberto. Op. Cit. p. 285

${ }^{105}$ MARTINS, Pedro Batista. Op. Cit. p. 277. 
necessário conceituar o que se entende como sendo "por escrito" e em que medida documentos eletrônicos atendem a tal determinação.

Antes de mais nada, deve-se atentar ao fato de que a tendência mundial é de conferir ao e-writing o mesmo peso e validade do documento físico ${ }^{106}$. Nesse sentido, veja-se a recomendação da UNCITRAL Model Law on International Commercial Arbitration, conforme alterada em 2006, já à luz dos avanços tecnológicos mundiais:

The requirement that an arbitration agreement be in writing is met by an electronic communication if the information contained therein is accessible so as to be useable for subsequent reference; "electronic communication" means any communication that the parties make by means of data messages; "data message" means information generated, sent, received or stored by electronic, magnetic, optical or similar means, including, but not limited to, electronic data interchange (EDI), electronic mail, telegram, telex or telecopy ${ }^{107}$.

A Convenção de Nova York, por sua vez, tendo sido elaborada em 1958 quando, como se viu no Capítulo 2 a respeito do surgimento dos ODRs, os contornos que o mundo eletrônico viria a tomar ainda eram pouco palpáveis, determina que a expressão "em escrito" engloba "an arbitral

\footnotetext{
106 "For example, Article (1316.1) of the French Civil Code, introduced by the Law of 13 May 2000 relating to E-Evidence (Loi sur la preuve électronique), states that 'writing' includes the use of new technologies for the conclusion of an agreement. Moreover, Article (1316.3) states that 'an electronic-based document has the same probative value as a paper-based document'. Accordingly, the writing requirement enshrined in Article (1443) of the New French Code of Civil Procedures governing the form of domestic arbitration agreements should be construed in light of Article 1316 paragraphs (1) and (3) of the Civil Code. The same principles should be applicable to the interpretation of the 'writing' requirement, which is enshrined in Article (10.2) of the Egyptian Arbitration Law, especially upon the enactment of the E-Signatures Law No.15 of 2004, which has given e-communications/documents/signatures the same probative value as paper-based documents. In England, the English Arbitration Act (1996) defines the 'writing' requirement enshrined in Section 5(6) as inclusive of 'being recorded by electronic means'. In the USA, Article 6(a) of the Federal Uniform Arbitration Act refers to 'an [arbitration] agreement contained in a record'. As per the Act the word 'record' means 'information that is inscribed on a tangible medium or that is stored in an electronic or other medium and is retrievable in perceivable form'. In Germany, Article 1031(5) of the German Code of Civil Procedure explicitly states that the 'written' form shall include 'electronic' form pursuant to Section 126(a) of the German Civil Code. The above are just examples of the tidal wave sweeping across the world and providing for the recognition of e-communications/documents/signatures, which certainly impacts the recognition of e-arbitration agreements in so far as certain conditions are fulfilled". (WAHAB, Mohamed S. Abdel. Op. Cit. pp. 406-407)

${ }^{107}$ Art. $7^{\circ}$ UNCRITRAL Model Law
} 
clause in a contract or an arbitration agreement, signed by the parties or contained in an exchange of letters or telegrams" 108.

Assim é que em 07 de julho de 2006, a UNCITRAL emitiu uma recomendação sobre a interpretação do artigo acima mencionado da Convenção de Nova York recomendando que as hipóteses ali estabelecidas não fossem tidas como exaustivas ${ }^{109}$. No entendimento de Mohamed S. Abdel Wahab a interpretação correta do artigo em questão à luz da recomendação da UNCITRAL é que "the writing'requirement should be broadly construed to encompass e-writing, especially if the relevant national law recognizes ecommunications, e-documents, and e-signatures" ${ }^{110}$.

Assim, fazendo-se uma interpretação contemporânea do requisito do art. 24 da Lei de Arbitragem de que a sentença seja escrita, é possível sob essa ótica uma sentença proferida exclusivamente online.

Além do requisito de que a sentença seja escrita, a Lei de Arbitragem também determina em seu art. 26 que a sentença arbitral deverá obrigatoriamente conter: (i) um relatório com o nome das partes e um resumo do litígio; (ii) os fundamentos da decisão; (iii) o dispositivo do que está sendo decidido; e (iv) a data e o lugar em que foi proferida a sentença.

Para a análise da compatibilidade dos serviços JUR com legislação brasileira sobre arbitragem, o requisito de maior relevância com relação à sentença é o último, sobretudo no que diz respeito ao lugar em que foi proferida a sentença. Isso porque, conforme explica Mohamed S. Abdel

\footnotetext{
${ }^{108}$ Artigo II da Convenção de Nova York.

109 "1. Recommends that article II, paragraph 2, of the Convention on the Recognition and Enforcement of Foreign Arbitral Awards, done in New York, 10 June 1958, be applied recognizing that the circumstances described therein are not exhaustive" (UNCITRAL. Recommendation regarding the interpretation of article II, paragraph 2, and article VII, paragraph 1, of the Convention on the Recognition and Enforcement of Foreign Arbitral Awards, done in New York, 10 June 1958 (2006).

Disponível

em $<$ https://uncitral.un.org/en/texts/arbitration/explanatorytexts/recommendations/foreign_arbitral_aw ards $>$ Acesso em 18 Nov. 2019)

${ }^{110}$ WAHAB, Mohamed S. Abdel. Op. Cit. p. 406
} 
Wahab, a determinação do local pode ser de grande dificuldade em arbitragens online:

In e-arbitration, the determination of the seat of arbitration gives rise to certain problems and challenges relating to the determination thereof in case the parties fail to agree on a specific seat of arbitration, as the proceeding normally takes place in virtual setting amongst parties and arbitrators that could be virtually dispersed ${ }^{111}$.

Isso porque, conforme explica Carlos Alberto Carmona, a Lei de Arbitragem brasileira optou por um critério objetivo e simplista para fins de determinação da nacionalidade da sentença arbitral, qual seja o lugar em que foi proferida a sentença ${ }^{112}$. Por isso a importância da sentença determinar o local em que foi preferida uma vez que este será o elemento nacionalizante ou internacionalizante da sentença, o que definirá, por exemplo, a competência para apreciar eventual anulação de sentença ${ }^{113}$.

Assim, para fins da legislação brasileira, pouco importa que a sentença tenha como objeto conflito entre partes estrangeiras ou tenha fundamento em outros ordenamentos jurídicos, importa apenas o local em que foi proferida:

"Será nacional a sentença arbitral se o laudo for proferido dentro do território brasileiro, ainda que os árbitros devam tratar de questão ligada ao comércio internacional e mesmo que estejam em jogo ordenamentos jurídicos variados; será estrangeiro o laudo arbitral se proferido fora do território nacional, ainda que sejam as partes brasileiras resolvendo controvérsia decorrente de contrato celebrado no Brasil e que aqui deva ser cumprido" ${ }^{114}$.

No mesmo sentido, Rodrigo Garcia da Fonseca:

Podem surgir, assim situações entranhas à primeira vista, mas que devem ser tratadas dentro da lógica legal. É possivel, por exemplo, que durante o processamento da arbitragem sejam realizados atos em diversas cidades ou diferentes países, mas tal circunstância não afetará a nacionalidade da sentença arbitral. Só o lugar em que a sentença for proferida afetará sua nacionalidade. Desta forma, os árbitros podem se reunir em locais diferentes para discutir o caso,

\footnotetext{
${ }^{111}$ WAHAB, Mohamed S. Abdel. Op. Cit. p. 422

${ }^{112}$ CARMONA, Carlos Alberto. Op. Cit. p. 350.

113 ROQUE, André Vasconcelos. LONGO, Samantha Mendes. Nacionalidade da Sentença Comentários ao AGIN 00622827-33.2009.8.19.0000. In Revista de Arbitragem e Mediação, 2010. pp. 309-327.

${ }^{114}$ CARMONA, Carlos Alberto. Op. Cit. p. 350
} 
para emitir ordens processuais durante o curso da arbitragem ou mesmo para realizar audiências com as partes e advogados, ouvir testemunhas e peritos, e nada disso afetará a sentença arbitral ${ }^{115}$.

Mohamed S. Abdel Wahab ao analisar o local da sentença em arbitragens online, estabelece alguns critérios para sua verificação tão somente nas hipóteses em que não houver consenso entre as partes acerca do local da sentença ${ }^{116}$. Vê-se, portanto, que se trata de matéria que pode ser objeto de negociação entre as partes estando, portanto, inserta no âmbito da autonomia da vontade. A UNCITRAL também segue na mesma linha:

If the parties have not previously agreed on the place of arbitration, the place of arbitration shall be determined by the arbitral tribunal having regard to the circumstances of the case. The award shall be deemed to have been made at the place of arbitration ${ }^{117}$.

Certo é, contudo, que a Lei de Arbitragem estabelece como requisito obrigatório do compromisso arbitral a previsão pelas partes de onde será proferida a sentença arbitral. Tal determinação não apenas confirma a característica convencional do local da arbitragem como também resolve a problemática acima, uma vez que torna obrigatório às partes estabelecer o local onde será proferida a sentença.

\footnotetext{
${ }^{115}$ FONSECA, Rodrigo Garcia da. Reflexões sobre a sentença arbitral. In Revista de Arbitragem, São Paulo, 2015. p. 43.

116 "The seat or place of arbitration, as the location where the award was made, is indeed relevant to the arbitration process, although such relevance is sometimes challenged by some scholars and practitioners. However, the seat or place of arbitration normally determines the nationality of an arbitral award which in turn distinguishes the courts of primary jurisdiction entrusted with any possible challenge or recourse against the arbitral award. The seat or place may also have certain overriding or supplementary rules that supersede or complement the applicable procedural rules chosen by the parties. In e-arbitration, the determination of the seat of arbitration gives rise to certain problems and challenges relating to the determination thereof in case the parties fail to agree on a specific seat or place of arbitration, as the proceedings normally take place in a virtual setting amongst parties and arbitrators that could be virtually dispersed. In the absence or failure to agree on a seat, some scholars advocate the view that the seat should be the place where the servers are located, or the place where the computer is based or where the emails of the arbitrator are sent and collected. However, it is submitted that the above criteria may be quite difficult and/or confusing to ascertain and may not be a true representation of the parties' intention or expectations. Accordingly, it is submitted that the prevailing criteria, in the absence of the parties' agreement on the seat or place, are: (a) the arbitral tribunal shall determine such seat of arbitration; (b) the earbitration provider shall determine the seat; or (c) the seat shall be that of the e-platform used for the conduct of the e-arbitral proceedings". (WAHAB, Mohamed S. Abdel. Op. Cit. p. 422).

117 Artigo 18(I) das Arbitration Rules da UNCITRAL.
} 
Assim, sendo o local da sentença matéria convencional e tendo a sentença atribuído um local, nos termos do art. 26, negar-lhe validade pelo simples fato de que ela não foi fisicamente assinada pelos árbitros no local indicado parece ser um formalismo excessivo. Quanto a esse ponto, deve-se atentar ao fato de que o judiciário brasileiro há muito publica sentenças digitais, assinadas eletronicamente, às quais é atribuído um local de prolação.

Por fim, a Lei de Arbitragem requer ainda que as sentenças arbitrais sejam assinadas pelos árbitros (art. 26, parágrafo único).

Conforme explica Mohamed S. Abdel, há duas maneiras de se proferir uma sentença eletronicamente: (i) a primeira é uma digitalização da via física da sentença, devidamente assinada pelos árbitros; e (ii) a segunda é a chamada e-award, proferida e assinada eletronicamente ${ }^{118}$.

A primeira hipótese, por envolver vias físicas de documentos e não se adequar ao modelo JUR de sentença, foge do objeto de análise deste trabalho. Já com relação à segunda, deve-se analisar a validade da manifestação eletrônica.

Sobre esse tema, Mohamed S. Adel leciona que, desde que as partes que estejam se manifestando e se relacionando eletronicamente tenham plena consciência de tal fato, suas manifestações serão válidas:

In so far as two agents engage in operations that signify agreement, or an individual knowingly interacts with an electronic agent an agreement is duly and validly formed ${ }^{119}$.

A doutrina estrangeira fala ainda de uma equivalência funcional das sentenças eletrônicas com as sentenças físicas quando for possível ter segurança quanto à sua integridade:

\footnotetext{
118 WAHAB, Mohamed S. Abdel. Op. Cit. p. 424.

${ }^{119}$ Ibid. p. 411
} 
Moreover, the proper implementation of the 'functional equivalence' doctrine entails that a digitally signed e-award satisfies the requirements of an original award when there is a reliable assurance of its integrity and when it is capable of being displayed to the concerned person to whom it should be presented for enforcement. Thus, when an electronic certificate is added at the end of an 'original' e-award to attest to the 'originality' of that award, or when data is automatically added by computer systems at the start and the finish of a data message in order to transmit it, such additions would be considered as if they were a stamp certifying the originality of the e-award ${ }^{120}$.

É exatamente nesse sentido que a nova Lei da Liberdade Econômica, Lei 13.874 de 20 de setembro de 2019, parece ir ao determinar que, em documentos particulares "qualquer meio de comprovação da autoria, integridade e, se necessário, confidencialidade de documentos em forma eletrônica é válido, desde que escolhido de comum acordo pelas partes ou aceito pela pessoa a quem for oposto o documento" ${ }^{\prime 21}$.

Assim, a sentença assinada eletronicamente na JUR não apresenta uma afronta ao requisito de assinatura da sentença pelos árbitros.

${ }^{120}$ Ibid. p. 426

${ }^{121}$ Art. 18 da Lei 13.874/2019 


\section{Conclusão}

O presente trabalho analisou o que são e como surgiram as Online Dispute Resolutions, apontando as disputas travadas no âmbito das relações e-commerce como a raiz desse novo instituto. Viu-se portanto que as $O R D s$ surgiram como uma forma de permitir que disputas mais simples, envolvendo valores menores pudessem ter uma tutela adequada no evento de um conflito.

Também foi visto que essa concepção inicial dos ODRs evoluiu muito desde sua criação, se tendo chegado hoje a plataformas de resolução de disputa online que comportem disputas mais complexas e que envolvam valores mais altos.

Nesse contexto, viu-se que a companhia suíça JUR busca criar uma plataforma online para toda a vida útil de um contrato, desde sua negociação até uma eventual disputa. Assim, a JUR oferece uma série de produtos que vão desde templates de contratos a métodos de resolução de disputa online que se valem da teoria dos jogos.

Como se viu também, para viabilizar sua plataforma a JUR faz uso da tecnologia blockchain que, entre outras utilidades, serve como uma forma bastante segura de se armazenar dados.

Entre os produtos oferecidos pela JUR está o Court Layer, que é uma forma de arbitragem online que se pretende oferecer decisões rápidas, de qualidade e com a mesma validade de uma sentença proferida em uma arbitragem tradicional offline.

Buscou-se então analisar a compatibilidade deste produto oferecido pela JUR com o ordenamento jurídico brasileiro, sobretudo no que diz respeito à Lei de Arbitragem. 
Como se viu, os procedimentos arbitrais são fortemente marcados pela autonomia da vontade das partes de forma que a análise da compatibilidade do procedimento arbitral online conforme oferecido pela JUR deve ser realizada sempre à luz da ampla liberdade de que gozam as partes em uma arbitragem.

A conclusão a que se chega, a partir da análise realizada no presente trabalho é a de que, observados determinados requisitos, não há impedimento no ordenamento pátrio a que um procedimento arbitral seja conduzido da forma prevista pela JUR.

Conforme explorado no presente trabalho, a arbitragem online pode ser extremamente interessante para as partes na medida em que reduz significativamente custos e permite que sejam dadas soluções com enorme rapidez. É preciso, portanto, que as partes contratantes de uma arbitragem lancem mão de fórmulas prontas para usarem da liberdade que thes é conferida de forma a desenhar procedimentos arbitrais que sejam verdadeiramente adequados às particularidades daquela relação e do tipo de conflito que pode surgir.

Nesse sentido, não obstante ser possível a condução de procedimentos arbitrais online, não está aqui a se sustentar que esta forma de resolução de disputas seria adequada a todo e qualquer tipo de disputa.

Como se viu, o Court Layer, a despeito dos benefícios que pode trazer às partes, também apresenta limitações na medida em que (i) limita a produção de provas e de manifestações; (ii) não permite às partes indicarem árbitros, ficando elas sujeitas à indicação sorteada pelo JUR; (iii) não permite a possibilidade de encontros físicos entre as partes, os árbitros e eventuais testemunhas; entre outras limitações exploradas neste trabalho. 
Tais limitações podem ser interessantes para determinadas partes que estejam dispostas a abrir mão de tais prerrogativas em troca de decisões mais rápidas e menos custosas. A análise de conveniência da adoção dessa forma de resolução de disputas, em função da natureza das limitações apresentadas, está intimamente ligada ao nível de complexidade envolvido em determinada disputa.

Assim, o procedimento arbitral online conforme oferecido pela JUR parece ser ideal para disputas de pequeno a médio valor que hoje não encontram guarida nos procedimentos arbitrais tradicionais. 


\section{Bibliografia}

BATES JR, Albert. TORRES-FLOWER, Zachary. Abuse of Due Process in International Arbitration: is due process paranoia irrational. In The American Journal of Construction Arbitration \& ADR, 2017.

Block Geeks. What is Blockchain Technology. Disponível em

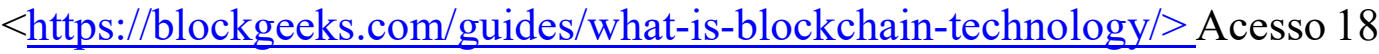
Nov. 2019.

BRAGHETTA, Adriana. Cláusula Compromissória - autossuficiência da cláusula cheia. In Doutrinas Essenciais Arbitragem e Mediação, 2014. pp. $33-42$.

CARMONA, Carlos Alberto. Arbitragem e Processo - Um comentário à Lei 9.307/96. São Paulo: Editora Atlas, 2004.

CASELLA, Paulo Borba Casella, Arbitragem - lei brasileira e praxe internacional. São Paulo: LTr, 1999.

CCI. ICC Commission Report. Controlling Time and Costs in Arbitration.

Disponível em $\quad<$ https://www.iccwbo.be/wpcontent/uploads/2012/03/20151101-Controlling-Time-and-CostsReport.pdf $>$ Acesso 18 Nov. 2019.

FALEK, Diego. ALVES, Rafael. Concordar em discordar: por quê, o quê e como negociar o procedimento arbitral. In Revista de Direito Empresarial, 2014.

FONSECA, Rodrigo Garcia da. Reflexões sobre a sentença arbitral. In Revista de Arbitragem, São Paulo, 2015. 
GERBAY, Remy. Due Process Paranoia. Disponível em $<$ http://arbitrationblog.kluwerarbitration.com/2016/06/06/due-processparanoia/> Acesso em 18 Nov. 2019.

Golder v. The United Kingdom. Disponível em: $<$ https:/hudoc.echr.coe.int/eng\#\{\%22itemid\%22:[\%22001-57496\%22]\}> Acesso em 18 nov. 2019.

GOMES, Orlando. Contratos. Rio de Janeiro: Forense, 2001.

GUERRERO, Luiz Fernando. Convenção de arbitragem e processo arbitral. São Paulo: Editora Atlas, 2009. p. 5.

HABER, Carolina Dzimidas. A produção da prova por videoconferência. In Revista Brasileira de Ciências Criminais, 2010

JUNIOR, Humberto Theodoro. Arbitragem e Terceiros - Litisconsórcio fora do pacto arbitral - outras intervenções de terceiros. In Reflexões sobre arbitragem in memoriam do Desembargador Cláudio Vianna de Lima. São Paulo: LTr, 2002.

JUR. White Paper. Disponível em: $<\underline{\text { https://jur.io/wp- }}$ content/uploads/2019/05/jur-whitepaper-v.2.0.2.pdf $>$ Acesso 18 Nov. 2019

KATSH, Ethan. WAHAB, Mohamed S. Abdel, RAINEY, Daniel. Online Dispute Resolution: Theory and Practice. A Treatise on Technology and Dispute Resolution. Hague: Eleven International Publishing.

KAUFMANN-KOHLER, Gabrielle. SCHULTZ, Thomas. Online Dispute Resolution: Challenges for Contemporary Justice. Hague: Kluwer Law International, 2004. 
KESAN, Jay P., SHAH, Rajiv C., Fool Us Once Shame on You - Fool Us Twice Shame on Us: What We Can Learn From the Privatizations of the Internet Backbone Network and the Domain Name System. Disponível em , $<$ https://papers.ssrn.com/sol3/papers.cfm?abstract id=260834> Acesso em 18 nov. 2001.

LEMES, Selma Maria Ferreira. Arbitragem. Princípios Jurídicos Fundamentais. Direito Brasileiro e Comparado. In Doutrinas Essenciais Arbitragem e Mediação, 2014.

LODDER, Arno R., CLARK, Eugene., GORDON, Thomas. F., KATSH, Ethan, RULE, Colin, THIESSEN, Ernest M., VERHEIJ, Bart, WALTON, Douglas. N, ZELEZNIKOW, John., Essays on legal en technical aspects of Online Dispute Resolution, Amsterdam: CEDIRE, 2004

MANIA, Korolina. Online Dispute Resolution: The future of justice. Pedagogical University of Cracow, Institute of Political Science, Poland. Disponível em $<$ https://reader.elsevier.com/reader/sd/pii/S2351667415000074?token=E38 4493F0DBAF7CF373AACD80FA6EDF19BC0480A6E8918D09ABCAB5 49585B8C5E0F0CC4816A23B4BFD566D55C07F559B $>$ Acesso em 18 nov. 2001.

MARTINS, Pedro Batista. Apontamentos sobre a Lei de Arbitragem. Rio de Janeiro: Forense, 2008.

NAKAMOTO, Satoshi. Bitcoin: A Peer-to-Peer Electronic Cash System.

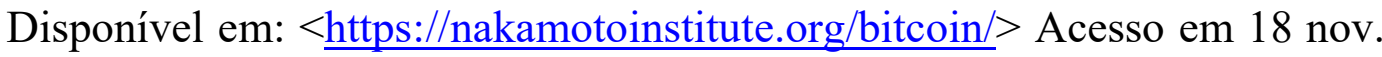
2019. 
NANNI, Giovani Ettore. Notas sobre os negócios jurídicos da arbitragem e a liberdade de escolha do árbitro à luz da autonomia privada. In Revista de Arbitragem e Mediação. 2016.

PINTO, José Emílio Nunes. A cláusula compromissória à luz do código civil. In Doutrinas Essenciais de Arbitragem e Mediação, 2014.

PUCCI, Adriana Noemi. Juiz \& Árbitro. In. Aspectos Atuais da Arbitragem. Rio de Janeiro: Forense, 2001

Queen Mary University of London. 2012 International Arbitration Survey: Current and Preferred Practices in the Arbitral Process. Disponível em < http://www.arbitration.qmul.ac.uk/media/arbitration/docs/2012 Internation al_Arbitration_Survey.pdf> Acesso em 18 Nov. 2019. . 2015 International Arbitration Survey: Improvements and Innovations in International Arbitration. Disponível em $<\underline{\text { http://www.arbitration.qmul.ac.uk/media/arbitration/docs/2015 Internatio }}$ nal_Arbitration_Survey.pdf $>$ Acesso em 18 Nov. 2019.

ROQUE, André Vasconcelos. LONGO, Samantha Mendes. Nacionalidade da Sentença - Comentários ao AGIN 00622827-33.2009.8.19.0000. In Revista de Arbitragem e Mediação, 2010

SHERMAN, Fredrick E. Sophisticated Arbitration. In. Arbitragem Interna e Internacional. Questões de Doutrina e da Prática. Coord. Ricardo Ramalho Almeida. Rio de Janeiro: Renovar, 2003.

TAPSCOTT, Don; TAPSCOTT, Alex. Blockchain Revolution: How the Technology Behind Bitcoin and Other Cryptocurrencies Is Changing the World. Nova York: Penguin, 2016. 
UNCITRAL. Recommendation regarding the interpretation of article II, paragraph 2, and article VII, paragraph 1, of the Convention on the Recognition and Enforcement of Foreign Arbitral Awards, done in New $\begin{array}{llllll}\text { York, } & 10 & \text { June } & 1958 & \text { (2006). Disponível em }\end{array}$ $<$ https://uncitral.un.org/en/texts/arbitration/explanatorytexts/recommendatio ns/foreign_arbitral_awards $>$ Acesso em 18 Nov. 2019

VERÇOSA, Fabiane. A liberdade das partes na escolha e indicação de árbitros em arbitragens internacionais: Limites e possibilidades. In Revista de Arbitragem e Mediação. São Paulo: Editora Revista dos Tribunais, 2004.

World Bank. Doing Business 2016. Disponível em < https://www.doingbusiness.org/content/dam/doingBusiness/media/AnnualReports/English/DB16-Full-Report.pdf> Acesso 18 Nov. 2019. 